\title{
A DEAL ISA DEAL: ANTENUPTIAL AGREEMENTS REGARDING THE RELIGIOUSUPBRINGING OF CHILDREN SHOULD BE ENFORCEABLE
}

\author{
JOCELYN E. STRAUBER
}

\section{INTRODUCTION}

Paul and Julie, Christian and J ewish, meet and eventually decide to marry. ${ }^{1}$ They plan to have children. B efore they marry, they discuss their religious differences and decide to determine what type of religious upbringing they will give their children. N either is devoutly religious, but Julie wants to raise her children as Jews and does not want them to attend church. Paul agrees to raise the children as J ews, but doesn't want them to miss out on some of the Christian traditions he enjoyed as a child. He'd like his children to celebrate Christmas and Easter at home. Julie agrees. She recognizes that agreements regarding religious upbringing are often difficult to enforce and suggests that they put theirs in writing. The agreement is

1. The following hypothetical is loosely based on the facts of several recent cases in which a couple decides, before they marry, what religious upbringing their prospective children will have. Paul and Julie's hypothetical agreement, however, is much more specific than any agreement made by the couples in those cases. See, e.g., Weiss v. W eiss, 49 Cal. R ptr. 2d 339, 341 (Cal. Ct. A pp. 1996) (reciting that mother made a pledge witnessed by three rabbis that all children would be raised J ewish); Sotnick v. Sotnick, 650 So. 2d 157, 159 (Fla. Dist. Ct. A pp. 1995) (noting that during their marriage the parents made a written declaration to the J ewish community to raise their son Jewish); Kirchner v. Caughey, 606 A.2d 257, 260 (M d. 1992) (observing that the parents "orally agreed," when their daughter was born, to raise her as a Catholic); K endall v. Kendall, 687 N.E.2d 1228, 1230 (Mass. 1997) (reciting that the parents agreed that their children would be raised in the Jewish faith); Hornung $\mathrm{V}$. Hornung, 485 N.W.2d 335, 336 (Neb. Ct. A pp. 1992) (noting that the parents were married in the Catholic church and agreed to raise their children as Catholics in the church); M acL agan v. K lein, 473 S.E.2d 778, 781 (N.C. Ct. A pp. 1996) (observing that the unmarried parents had agreed to raise their daughter in the Jewish faith); Zummo v. Zummo, 574 A .2d 1130, 1141 (Pa. Super. Ct. 1990) (noting that the parents discussed their religious differences and agreed to raise their children in the J ewish faith). 
very important to her and although neither acknowledge it, they might not be married without it.

Paul and J ulie draft an agreement detailing every aspect of their prospective children's religious education that will occur outside the home. They agree that in their home they will be free to discuss religion with their children, to decorate their house for religious holidays, and to celebrate the rituals and observe the traditions important to each of them. But they also agree that their children will receive a Jewish upbringing with respect to the religious activities that occur outside the home. The agreement covers the children's naming ceremonies, synagogue membership, religious education, religious activities (such as playgroups, picnics, dances and afterschool workshops run by their synagogue), and religious rites of passage such as bar and bat mitzvahs. They agree that they will not bring their children to church services, religious school, or other religious activities and that their children will not be, baptized or participate in other Christian rites of passage such as confirmation. Their agreement also includes definitions of the terms used. For example "church services" is defined to exclude family events such as weddings, funerals, and baptisms for their friends and family. The term "religious activities" is defined to include all church-sponsored activities, such as camps, afterschool programs and retreats, whether or not those activities have an express religious purpose. ${ }^{2}$ The agreement also includes a statement that both parties intend for it to apply in the event of divorce and that they both knowingly and willingly assent to its terms. When their children are born, they raise them as J ews as they agreed.

A fter ten years of marriage and two children, Paul and J ulie divorce. They are granted joint legal custody. The children live with Julie during the week, and with Paul on all weekends and school vacations. Several months after the divorce, the children tell J ulie that Paul has been taking them to church services on Sunday mornings for several weeks. Julie reminds Paul of their agreement and asks him to stop taking the children to church. Paul refuses to abide by the

2. This agreement does not seek to entirely preclude either party from sharing religious beliefs with his or her children-a process that is arguably as central to a religious upbringing as attendance at religious services. It seeks only to identify those areas of religious upbringing that could be the subject of an enforceable contract. In that sense, the agreement is a compromise. A ll children of an interfaith marriage will likely be influenced by the religious beliefs of both of their parents. But an agreement such as this one would allow a parent to ensure that her children receive formal religious training in one religion only. 
agreement, explaining that his religion has become more important to him since his marriage. He wishes to share his beliefs and traditions with his children, at formal services as well as in his own home. J ulie seeks a court order to enforce the agreement.

Interfaith marriage is relatively common in the $U$ nited States today. ${ }^{3}$ The percentage of J ews who marry G entiles has been rising steadily since the early 1900 s and is now at just over fifty percent. ${ }^{4}$ The comparable intermarriage figure for $C$ atholics is twenty-one percent, for Mormons, thirty percent and for Muslims, forty percent. ${ }^{5}$ O ne of the most difficult questions an interfaith couple faces is that of the religious upbringing of their children. ${ }^{6}$ M any couples discuss this issue before they marry and make some kind of agreement about their children's religious upbringing. ${ }^{7}$ Some agreements are explicit, while others may be deemed implied-perhaps by one spouse's decision to convert to the other spouse's faith. ${ }^{8}$ Such agreements, if ex-

3. The hypothetical and the majority of cases cited in this $\mathrm{N}$ ote involve J ews who marry Christians, but the argument applies to all interfaith marriages, regardless of the faith of either parent.

4. SeeEllen Jaffe McClain, Embracing the Stranger: IntermarRiage and the Future OF THE A MERICAN JEWISH COMMUNITY 10 (1995).

5. See J erry A dler, A M atter of Faith, NEWSWEEK, D ec. 15, 1997, at 48, 50.

6. See Egon Mayer, Love and Tradition: Marriage Between Jews and CHRISTIANS 10 (1985) (stating that the subject of interfaith marriage "arouses strong feelings and challenges deeply held convictions"); REGER C. SMITH, TWO CULTURES, ONE MARRiage: Premarital Counseling for MiXed MarRiages 40 (1996) (noting that decisions about the religious upbringing of children are a "major problem" for interfaith couples); Leo Pfeffer, Religion in the U pbringing of Children, 35 B.U. L. REV. 333, 333 (1955) (claiming that there are few other areas of litigation that can evoke stronger and more impassioned reactions than parents who are in court over the religious upbringing of their children). A mong J ewishG entile couples, $27.8 \%$ reported that they were raising their children as J ews, $30.8 \%$ said that they were raising their children without religion and $41.4 \%$ that they were raising children in a religion other than J udaism. See MCCLAIN, supra note 4, at 10.

7. Several counselors have suggested that handling this issue prior to marriage is most likely to reduce potential parental conflicts that may arise later. See RoY A. ROSENBERG ET A L., H A PPILY INTERM A R RIED 135-36 (1988) (discussing the various alternatives that ChristianJ ewish interfaith couples may choose once their children are born, but noting that "ideally, father and mother should have decided this before their wedding").

8. See, e.g., A bbo v. B riskin, 660 So. 2d 1157, $1158-59$ (Fla. D ist. Ct. A pp. 1995) (explaining that the wife converted to J udaism as a condition of marriage, thereby suggesting that she agreed to raise any children of the marriage as J ews). 
plicit, generally consist of vague promises, either oral or written, about the faith in which the couple's children will be raised. ${ }^{9}$

W hile these agreements may pose few problems during the marriage, frequently, upon divorce, one parent breaches the agreement. ${ }^{10}$ She brings the children to a church or synagogue although she had agreed not to and had not done so prior to divorce. He discusses religion in a manner that she considers "indoctrination." Thus far, those parents who have sought to enjoin such behavior on the basis of an antenuptial religious upbringing agreement have failed. ${ }^{11}$ Courts generally have refused to restrict either a parent's religious activity with his or her children or a parent's religious discussions with his or her children on the basis of such an agreement. ${ }^{12}$ Courts either ignore the agreement entirely or conclude that the agreement is unenforceable. ${ }^{13}$ Courts will restrict a parent from engaging in religious activities that threaten to "harm" the children, but are otherwise reluctant to curtail either parent's ability to influence his or her children's religious upbringing. ${ }^{14}$ In fact, a court will structure custody or visitation to enable each parent to do so. ${ }^{15}$

Courts refuse to enforce antenuptial religious upbringing agreements under standard contract principles when the agreements are so vague that the courts cannot determine to what the parties agreed. ${ }^{16}$ Most agreements don't explicitly provide for enforcement upon divorce; some courts describe divorce as an unforeseen event that in-

9. See, e.g., Weiss, 49 Cal. R ptr. $2 d$ 339, 341 (Cal. Ct. A pp. 1996) (stating that the mother executed a declaration of faith, witnessed by three rabbis, pledging to rear all her children in loyalty to the J ewish faith and its practices); Sotnick v. Sotnick, 650 So. 2d 157, 159 (Fla. D ist. Ct. A pp. 1995) (stating that parents, during their marriage, made a written declaration to "enter their minor son into G od's covenant with I srael"); In re Marriage of Neuchterlein, 587 N.E.2d 21, 22 (III. A pp. Ct. 1992) (indicating that prior to marriage the parties had orally agreed to raise any future children in the Lutheran faith); K irchner v. Caughey, 606 A .2d 257, 260 ( $M$ d. 1992) (recounting the mother's claim that the parties had orally agreed to raise their child in the Catholic faith); Zummo v. Zummo, 574 A .2d 1130, 1141, 1145 (Pa. Super. Ct. 1990) (noting that prior to marriage the parties orally agreed that their children would be raised as Jews).

10. See cases cited supra note 1 . This $N$ ote does not address the role such an agreement might play in regulating the ongoing marriage.

11. See cases cited supra note 1 .

12. See Kendall v. Kendall, 687 N.E.2d 1228, 1230 n.5 (M ass. 1997) (noting that "[t]he majority of courts adhere to the view that predivorce agreements are unconstitutionally [sic] unenforceable"); see also infra Part III.A.

13. See infra Part I.B .

14. See infra notes $28-35$ and accompanying text.

15. See infra notes $45-50$ and accompanying text.

16. See infra notes $78-86$ and accompanying text. 
validates the agreement. ${ }^{17}$ Courts also hold that enforcement of these contracts would violate the E stablishment and Free Exercise Clauses of the Constitution. ${ }^{18}$ They find that enforcement requires the court to determine the content of a religious upbringing and to oversee and supervise religious matters; and may impermissibly involve the court in the oversight and supervision of religious matters. ${ }^{19}$ Courts find that enforcement violates the Free Exercise Clause because it interferes with a parent's right to contribute to his or her children's religious upbringing. ${ }^{20}$

This N ote argues that courts should enforce antenuptial religious upbringing agreements that resemble the agreement made by Paul and Julie. Courts correctly refuse to enforce vague agreements that consist of promises to raise one's children in a particular faith, or to issue broad orders that prohibit a parent from exercising any religious influence over his or her children. However, a written, specific agreement, limited to religious rituals and activities which occur outside the home can be enforced, based on neutral principles of contract law, without violating constitutional principles of religious freedom.

Part I of this Note discusses the courts' approach, across jurisdictions, to child custody and visitation disputes where the parents practice different religions and religion is a factor in their disputes. It compares the courts' approach to conflicts regarding a child's religious upbringing in situations where parents do not have an antenuptial religious upbringing agreement and in situations in which they do have such an agreement. Part II discusses the judicial rationale for nonenforcement of these agreements based on contract principles. It critiques that rationale and offers alternatives to it, in support of enforcement. Part III discusses the judicial rationale for nonenforcement of these agreements based on constitutional principles, critiques that rationale and offers alternatives to it, in support of enforcement. A $n$ A ppendix to the Note presents a model antenuptial religious upbringing agreement that a court could enforce under the reasoning suggested.

17. See infra note 87 and accompanying text.

18. See infra Part III.A.

19. See infra Part III.A .1-2.

20. See infra Part III.A.3. 


\section{The COURTS' A PPROACH TO RELIGIOUSISSUESIN CUSTOdY OR VISITATION DISPUTES}

\section{A. Situations Where P arents $\mathrm{H}$ ave $\mathrm{N}$ o A ntenuptial A greement Regarding R eligious U pbringing}

To understand the courts' treatment of antenuptial religious upbringing agreements, it is necessary to first examine the broad range of religious issues in child custody disputes generally. Courts often rely on general principles that govern custody disputes involving religious issues to resolve a dispute in which the parents have a religious upbringing agreement, rather than addressing the enforceability of the agreement itself. A lso, as few courts have addressed the enforceability of religious upbringing agreements, those courts who discuss their enforceability do so within the framework of those general principles.

The religious upbringing a parent provides may or may not be explicitly identified as a factor for the court to consider in making a custody award. Children custody statutes vary slightly by state and custody cases vary widely by state, by court and by case. ${ }^{21}$ In most states, state statutes direct the courts to determine the best interests of the child and make the custody award on that basis. The courts have broad discretion to make that determination, as most state statutes simply identify a number of general factors that courts might find relevant to the child's best interests. ${ }^{22}$ Some statutes include the

21. In addition to providing different guidelines for custody determinations, states also offer different custody arrangements. For example, some states provide for both joint legal custody arrangements, in which both parents have the right to make all decisions affecting their children's welfare, and sole custody arrangements, in which those determinations are made exclusively by one parent. See, e.g., A L. STAT. §§ 30-3-150 to 30-3-152 (Michie Supp. 1997) (expressing the state policy of assuring frequent and continuing contact with both parents, and defining joint physical or legal custody); ARIZ REV. STAT. § 25-402 (West Supp. 1997) (defining joint legal and physical custody, as well as sole custody); CAL. FA M. CODE $\S \S 3002-$ 3004, 3006-3007 (West 1994); MAsS. A NN. LA Ws ch. 208, § 31 (Law. Co-op. 1994) (defining sole legal custody, shared legal custody, shared physical custody).

22. See, e.g., CAL. FAM. CODE $\S 3011$ (West Supp. 1998) (directing court to consider any relevant factors, always to include those specified in statute, primarily directed toward health, safety, and welfare of child); GA. CODE A NN. § 19-9-3(a)(2) (Supp. 1997) (a court resolving a custody dispute may "take into consideration all circumstances of the case"); KY. REV. STAT. A NN. §403.270(1)(a)-(f) (Banks-Baldwin 1990) (directing court to determine best interests of child, considering "all relevant factors," including the wishes of parent, wishes of the child, interaction of child with parents and siblings, adjustment to home, school and community, mental health of all individuals, and information and records of domestic violence); M A SS. A NN. LA WS ch. 208, § 31 (L aw. Co-op. 1994) (directing court to consider the "happiness and welfare of the 
child's "adjustment to religion" as one of the factors. ${ }^{23}$ The courts focus on the interests of the children, not the rights of the parents. ${ }^{24}$

A t the same time, however, a court cannot make a custody award that expresses a preference for one parent's religion over the other's. To discriminate between persons on the basis of religion is clearly unconstitutional, ${ }^{25}$ and a custody determination improperly based on religious bias violates a parent's constitutional rights. ${ }^{26} \mathrm{As}$ a general rule, courts refuse to weigh the merits of a parent's religion in making custody determinations, even when that religion will clearly affect the children's lifestyle. ${ }^{27}$

child," and describing factors that should be weighed); NEB. REV. STA T. A N N. § 42-364 (M ichie 1995 \& Supp. 1997) (setting forth an extensive list of factors including: general considerations of moral fitness; the parent's sexual conduct; the emotional relationship between the children and the parents; and the attitude and stability of the parent's character). Some states simply ask the court to consider the children's best interests, without further clarification. See, e.g., N.Y. D OM. REL. LAW $\S 240$ (M CK inney Supp. 1997-1998) (stating that the court "shall enter orders for custody and support as, in the court's discretion, justice requires, having regard to the circumstances of the case and of the respective parties and to the best interests of the child").

23. See WIS. STAT. A NN. § 767.24(5)(b) (West 1993) (directing court to consider "[t]he child's adjustment to the home, school, religion and community").

24. See R. Collin M angrum, Exclusive Reliance on B est Interest M ay Be Unconstitutional: Religion as a Factor in Child Custody Cases, 15 CREIGHTON L. REV. 25, 44 (1981).

25. See County of A llegheny v. A CLU , 492 U .S. 573, 590 (1989) (stating that "this Court has come to understand [that] ... government may not ... discriminate among persons on the basis of their religious beliefs and practices"); see also Note, The E stablishment Clause and Religion in Child Custody D isputes: Factoring Religion into the B est I nterest E quation, $82 \mathrm{M} \mathrm{ICH}$. L. REV. 1702, 1720 (1984) (arguing that basing custody decisions on religion violates the Establishment Clause "by putting the authority, influence, official support and coercive power of the state behind religion").

26. See Zucco v. Garrett, 501 N.E.2d 875, 888 (III. A pp. Ct. 1986) (stating that a court's preference for a parent's participation in organized religion in awarding child custody would directly and immediately advance religion); Pater v. Pater, 588 N.E.2d 794, 798 (O hio 1992) (citing Palmore v. Sidoti, 466 U.S. 429 (1984) (holding that courts cannot implement private racial prejudices, even those widely held by the population)); see also Bonjour $v$. B onjour, 592 P.2d 1233, 1243 (A laska 1979) (explaining that preferring parents who are members of an organized religious community over those who are not will encourage nonreligious parents to engage in religious practices even if their beliefs are insincere).

27. See, e.g., Quiner v. Quiner, 59 Cal. R ptr. 503, 517-18 (Cal. Ct. A pp. 1967) (rejecting argument that mother's affiliation with sect that prohibited social contact with non-members, participation in civic or political activities, ownership of radios or televisions and giving toys to children was necessarily contrary to her child's best interests); G arrett v. G arrett, 527 N.W .2d 213, 221 ( $\mathrm{N} \mathrm{eb.} \mathrm{Ct.} \mathrm{A} \mathrm{pp.} \mathrm{1995)} \mathrm{(refusing} \mathrm{to} \mathrm{reverse} \mathrm{custody} \mathrm{award} \mathrm{to} \mathrm{mother} \mathrm{on} \mathrm{the} \mathrm{basis} \mathrm{of} \mathrm{her}$ religious practices as a J ehovah's W itness, and rejecting father's argument that the harm caused by those practices, such as confusion and separation from other children, amounted to the requisite "immediate and substantial threat" to a child's health and welfare); Pater v. Pater, 588 N.E.2d 794, 799-80 (O hio 1992) (reversing a custody award to father that was based on evidence that mother, a Jehovah's Witness, would forbid children to celebrate holidays, be in- 
It is generally only when a court finds that one parent's religion poses an actual threat to a child's mental or physical health, or a substantial likelihood of harm to that child's health or welfare, that a parent's religion becomes relevant to a custody determination. ${ }^{28}$ In that situation, a court will consider a parent's religiously motivated behavior in making a custody determination. ${ }^{29}$ Such findings are rare, however, as most courts require concrete evidence of actual impairment of a child's well being. ${ }^{30}$ This high standard of harm represents the judicial attempt to balance the state's concern for a child's welfare against each parent's right to freely practice his or her religion, free from a court's evaluation of its merits.

Courts apply the same standard of harm when a parent seeks to modify a prior custody or visitation decree by an order restricting the other parent's freedom to expose his or her children to a particular religion, or by an order requiring that parent to raise his or her children in a particular religion. In general, each parent is free to discuss religion with his or her children, take them to religious services or engage in other religious activities with them when he or she has custody $\mathrm{y}^{31}$ or during periods of visitation. The noncustodial parent has

volved in extracurricular activities or salute the flag as an unconstitutional evaluation of the merits of a parent's religion); Gould v. Gould, 342 N.W.2d 426, 432-33 (Wis. 1984) (holding that trial court abused its discretion in transferring custody from mother to father based on belief that religious affiliation furnished by father would be better than absence of religious affiliation in mother's home); see also D onald L. B eschle, God Bless the Child?: The U se of Religion as a Factor in Child Custody and Adoption Proceedings, 58 FORDHAM L. REV. 383 (1989) (exploring the constitutional questions raised by the use of religion as a factor in child custody cases).

28. See Bienenfeld v. Bennett-White, 605 A .2d 172, 182-85 (M d. Ct. Spec. A pp. 1992) (holding that since the mother attempted to restrict the children's access to the father because of her religious views and the resulting conflict between the parents adversely affected the son's mental well being, consideration of religion was appropriate); Burnham v. Burnham, 304 N.W.2d 58, 61-62 (Neb. 1981) (holding that the mother's religious beliefs would have a "deleterious effect... . on the relationship between the father and his daughter [and] upon the well-being of the child herself").

29. For instance, in Prince v. M assachusetts, 321 U .S. 158, 169-70 (1944), the Court upheld the application of state child labor laws to prohibit street preaching by children, even when children are accompanied by a guardian. The Court noted that children could suffer physical and psychological injuries if permitted to preach along highways. See id. at 170 . Presumably, a parent's behavior in encouraging a child to participate in such conduct could be considered in a custody determination proceeding, despite the parent's underlying religious motivation.

30. See B eschle, supra note 27 , at 401.

31. Custody arrangements will vary in each case. Beginning in the late 1970s, a large number of states began enacting joint custody laws. See B eschle, supra note 27, at 389 n.36. In a joint legal custody arrangement, both parents are involved in the major decisions regarding a child's welfare. See, e.g., M A SS. A NN. L A ws. ch. 208, § 31 (L aw. Co-op. 1994) (defining "shared legal custody" as "continued mutual responsibility and involvement by both parents in major 
this right even when the other parent has sole custody. ${ }^{32}$ Sole legal custody frequently confers authority over a child's religious upbringing. ${ }^{33}$ The majority of courts hold that a custodial parent who seeks a court order restricting the noncustodial parent's activities will be required to make a clear and affirmative showing that exposure to conflicting religions will cause substantial harm to the children. ${ }^{34}$ In the absence of a clear threat to the child's welfare, courts are reluctant to interfere with either parent's right to practice religion with his or her children, in whatever way he or she chooses to do so. ${ }^{35}$

decisions regarding the child's welfare including matters of education, medical care, and emotional, moral and religious development" and defining "sole legal custody" as granting one parent "the right and responsibility to make major decisions regarding the child's welfare including matters of education, medical care and emotional, moral and religious development"). If one parent has sole custody, the child will reside with that parent and that parent will make all decisions regarding the child's welfare, subject to reasonable visitation by the other parent. See id.

32. See, e.g., M urga v. Petersen, 163 Cal. R ptr. 79, 82 (Cal. Ct. A pp. 1980) (noting that in the majority of $A$ merican jurisdictions, courts have refused to restrain the noncustodial parent from exposing the children to his or her religious practices without a clear showing of harm).

33. See, e.g., Colo. REv. STAT. § 14-10-130 (1997) ("The custodian may determine the child's upbringing, including his education, health care, and religious training...."), MASS. A NN. LA WS. Ch. 208, § 31 (L aw. Co-op. 1994) (defining the responsibilities associated with sole custody, including authority to make major decisions regarding a child's religious development).

34. See K evin S. Smith, N ote, R eligious Visitation Constraints on the N oncustodial Parent: The N eed for $N$ ational A pplication of a U niform Compelling Interest T est, 71 IND. L.J . 815, 820 (1996) (discussing the substantial harm standard, and arguing that despite its consistent application, the standard's vague language fails to ensure a consistent level of protection for the noncustodial parent's rights).

35. See, e.g., M urga, $163 \mathrm{Cal}$. R ptr. at 82 (noting that "the majority of A merican jurisdictions... have refused to restrain the noncustodial parent from exposing the minor child to his or her religious beliefs and practices, absent a clear, affirmative showing that these religious activities will be harmful to the child"); K irchner v. Caughey, 606 A .2d 257, 260-64 (M d. 1992) (holding that a restriction barring noncustodial father's ability to have the child participate in any church related activity was too broad, but suggesting that activities that involve "proselytizing" should be prohibited to the extent that the noncustodial parent's religious practices were causing the child to experience harmful emotional distress); Fisher v. Fisher, 324 N.W.2d 582, 585 (M ich. Ct. A pp. 1982) (refusing to order the custodial mother to continue the children's Christian education and training at the request of the father, without a showing that the mother's religious "practices threaten the children's well being"); $\mathrm{H}$ anson $\mathrm{v}$. $\mathrm{H}$ anson, 404 N.W.2d 460, 464 (N.D. 1987) (holding that the affliction of psychological stress on children resulting from the noncustodial father's attempts to impose his religious beliefs upon them fell short of a clear affirmative showing of physical or emotional harm); M unoz v. M unoz, 489 P.2d 1133, 1135 (Wash. 1971) (finding that constitutional requirement of impartiality between religions prohibits limitations on a parent's religious practices with his or her children in the absence of a clear and affirmative showing that the children's welfare is detrimentally affected by those practices). 
$\mathrm{N}$ evertheless, decisions on this point are inconsistent. The terms "harm" and "threat to well being" are capable of numerous constructions. Some courts seem willing to label many types of emotional stress as "harm" and restrict parents on that basis; ${ }^{36}$ others require a showing of greater mental or physical harm. ${ }^{37}$ M ost courts apply either an actual or substantial threat of harm standard, however, regardless of whether the parents have a joint custody arrangement or a sole custody arrangement. ${ }^{38}$ In a joint custody arrangement, courts protect each parent's right to engage in religious activities. ${ }^{39}$ By the nature of a sole custody with visitation arrangement, the parent with visitation rights can engage in religious activities during his or her periods of visitation; the sole custodian can do so at all other times.

In adjudicating custody disputes involving religion, the court both seeks to protect the parent's constitutional rights, and to safeguard the welfare of the children. ${ }^{40}$ While courts have applied the

36. See, e.g., Funk v. O ssmann, 724 P.2d 1247, 1250-51 (A riz. Ct. A pp. 1986) (prohibiting a noncustodial father from taking his children to J ewish religious training during visitation periods because of the detrimental effect of the J ewish training upon the child's welfare); L edoux $v$. Ledoux, 452 N.W.2d 1, 5 (Neb. 1990) (holding that the psychological stress experienced by children due to their parents' conflict over religion was sufficiently harmful to justify an order restricting $\mathrm{Mr}$. Ledoux from exposing the children to any practices inconsistent with those taught by M rs. Ledoux, the custodial parent); B entley v. B entley, 448 N.Y .S.2d 559, 560 (N.Y . A pp. Div. 1982) (finding emotional strain emanating from parents' conflict over religion sufficient to justify order prohibiting a noncustodial parent from instructing children in Jehovah's Witness' teachings and from taking them to religious and social activities); S.E.L. V. J.W.W., 541 N.Y .S.2d 675, 679 (N.Y. Fam. Ct. 1989) (allowing a father to take his daughter to J ehovah's Witness' services but prohibiting any further exposure to the religion because it threatened to cause psychological "strain and conflict"); MacL agan v. K lein, 473 S.E.2d 778, 787 (N.C. Ct. A pp. 1996) (affirming the modification of custody order by awarding joint custody to nonJ ewish mother and J ewish father and ordering mother to cooperate in father's program of religious training, because of finding that child has a positive sense of identity as a J ew and interference with that will impact her emotional well being).

37. See M urga, $163 \mathrm{Cal}$. R ptr. at 82 (reversing portion of an order which restricted noncustodial father from discussing religious activities with his child despite evidence of child's anxiety and temper tantrums prior to his visits with his father), see also cases cited supra note 27.

38. See cases cited supra note 36 (barring religious activity when causing either actual or threatened harm).

39. See, e.g., Zummo v. Zummo, 574 A .2d 1130, 1157 (Pa. Super. Ct. 1990) (holding that when parents have joint physical and legal custody, each is entitled to engage in religious activities with his or her children during periods of lawful custody and visitation in the absence of a showing that doing so presents a risk of substantial harm to the children).

40. See Felton v. Felton, 418 N.E.2d 606, 607-08 (M ass. 1981) (noting that although the dominant goal is to serve the child's best interest, that does not require courts to curtail one parent's liberties by limiting his religious influence). In Zummo, the court held that:

[I ]n order to justify restrictions upon parent's rights to inculcate religious beliefs in their children, the party seeking the restriction must demonstrate by competent evidence that the belief or practice of the party to be restricted actually presents a sub- 
"harm" or "threat" standard inconsistently, the use of that standard, as opposed to the more flexible best interest standard, suggests that courts are reluctant to interfere with a parent's constitutionally protected right to control the religious upbringing of his or her children. ${ }^{41}$ While courts will step in when necessary to protect a child from harm, they seek to leave questions of religious upbringing to the parents where it is possible to do so. In the context of an interfaith divorce, most courts are unwilling to find harm merely because a child is exposed to two contrary religions. ${ }^{42} \mathrm{As}$ a governing principle, courts find that "the question of a child's religion must be left to the parents even if they clash[, as a] child's religion is no proper business of judges." ${ }^{43}$ M oreover, the court

cannot regulate by its processes the internal affairs of the home.... The vast majority of matters concerning the upbringing of children must be left to the conscience, patience, and self restraint of father and mother. No end of difficulties would arise should judges try to tell parents how to bring up their children. ${ }^{44}$

stantial threat of present or future physical or emotional harm to the particular children.

Zummo, 574 A .2d at 1156.

For a contrary view, see generally Carl E. Schneider, Religion and Children Custody, 25 U. MICH. J.L. REFORM 879 (1992) (examining the L edoux decision). Schneider concludes that the "immediate and substantial threat" test is, in fact, a best interests test, that is particularly tolerant of judicial intervention and seems to invite courts to optimize a child's circumstances. Id. at 898-99.

41. Cf. Schneider, supra note 40 , at 900 (noting that "[t]he best-interest standard is always troublesome because it ignores parental interests" and makes intervention "markedly too easy").

42. See F elton, 418 N.E.2d at 607-08 (noting that " $[$ t]here may also be a value in letting the child[ren] see, even at an early age, the religious models between which it is likely to be led to choose in later life"); see also M entry v. Mentry, 190 Cal. R ptr. 843, 847 (Cal. Ct. A pp. 1983) (citing Felton and endorsing a child's exposure to the religious views of his or her parents, despite their disparity); I ra C. L upu, The Separation of Powers and the Protection of Children, 61 U. CHI. L. REV . 1317, 1348-50 (1994) (arguing that although a child may experience religious confusion when confronted with two distinct "brand[s]" of religion, allowing multiple influences prevents the domination of one parent's religious tradition and "leave[s the child] free to grow into his own, undominated adult self").

43. A bbo v. B riskin, 660 So. $2 d$ 1157, 1161 (Fla. D ist. Ct. A pp. 1995). Courts also seem to fear that impinging in any way upon the parent-children relationship might "limit or destroy the relationship." See Fatemi v. Fatemi, 489 A .2d 798, 800 (Pa. Super. Ct. 1985) (holding that restrictions on the parent-child relationship ought not be imposed unless it can be shown that some detrimental impact will flow from the specific behavior of the parent).

44. M entry, 190 Cal. R ptr. at 848 (citing Sisson v. Sisson, 2 N.E.2d 660, 661 (N.Y . 1936)); see also Schwarzman v. Schwarzman, 388 N.Y.S.2d 993, 997-98 (N.Y. Sup. Ct. 1976) (noting that $\mathrm{N}$ ew $\mathrm{Y}$ ork has "Iong pursued a policy of non-intervention in the internal management of 
If a parent asks a court to alter visitation to make it possible, or more convenient for that parent to involve his or her child in religious activities, most courts will issue such orders, without a showing of harm to the child in the absence of such orders. ${ }^{45}$ The majority of courts characterize these orders as "accommodations" and find that they are constitutionally permissible because they seek to protect each parent's right to "inculcate religious beliefs" in their children. ${ }^{46}$ In some cases, these orders simply permit both parents to celebrate their respective religious holidays with their children. ${ }^{47}$ Some courts use this characterization even when these orders appear to infringe on one parent's right to direct religious upbringing. For example, an order might require one parent to bring his or her children to a religious service or school, during his or her visitation, at the request of the other parent. ${ }^{48}$ In other cases, the order might have the practical effect of precluding one parent from taking his or her children to religious services. If, for example, an order modifies custody so that one parent has visitation on Sunday mornings and the other parent wishes to bring his or her children to church at that time, the order effectively interferes with one parent's freedom to direct his or her child's religious upbringing. ${ }^{49}$ Courts defend these orders as constitu-

the family" and refusing to order a Catholic custodial mother to raise her children J ewish, at the request of the noncustodial father).

45. Courts call these orders "accommodations" as opposed to "restrictions." See infra note 53. The term "accommodation" exposes the inherent tension between the Establishment Clause and the Free Exercise Clause of the First A mendment. Simply put, the state is not allowed to interfere with the exercise of religion and at times must make affirmative accommodations for religious practice. $\mathrm{O} n$ the other hand, those accommodations cannot rise to the level of a "law respecting an establishment of religion." U.S. CONST. amend. I.; L awrence C. Marshall, Comment, The Religion Clauses and Compelled Religious Divorces: A Study in M arital and Constitutional Separations, 80 N w. U. L. Rev V. 204, 204 (1985).

46. Zummo v. Zummo, 574 A .2d 1130, 1158 (Pa. Super. Ct. 1990) (upholding order requiring the father to present his children at synagogue Sunday school at the request of the mother during his period of visitation).

47. See Sanborn v. Sanborn, 465 A .2d 888, 894 (N.H. 1983) (vacating portions of divorce decree relating to visitation in order to permit both parents to celebrate the holidays of their respective religions with their children).

48. See J ohns v. J ohns, 918 S.W.2d 728, 730 (A rk. Ct. A pp. 1996) (upholding order requiring noncustodial father to bring his children to church services in accordance with the religious training program established by the custodial mother); Grayman v. Hession, 446 N.Y .S.2d 505, 506 (N.Y. A pp. D iv. 1982) (ordering Catholic custodial parent to enroll her child in an after-school H ebrew school program at the request of the noncustodial parent).

49. See, e.g., Rinehimer v. Rinehimer, 485 A.2d 1166, 1168-69 (Pa. Super. Ct. 1994) (upholding partial custody schedule which effectively prohibited the father from taking his minor sons to church services, thereby precluding him from exposing them to the formal practices of his religious faith); Burrows v. Brady, 605 A .2d 1312, 1315-16 (R.I. 1992) (holding that cus- 
tionally permissible by explaining that their goal is to support each parent's right to direct religious upbringing, not to restrict it. ${ }^{50}$

Courts do not clearly explain why these orders pose no Constitutional concerns. ${ }^{51}$ Some courts minimize the intrusion that the order poses to a parent's own religious freedom..$^{52} 0$ ther courts explain that the intrusion merely respects that parent's authority to direct the children's religious upbringing. ${ }^{53}$ Still other courts assert that the order focuses on the children's welfare and that any incidental infringement on a parent's religious freedom is constitutionally insignificant. $^{54}$ In general, courts appear comfortable with such orders because their express purpose is not to restrict the religious freedom of either parent. Nonetheless, as a practical matter, some orders do preclude a parent from involving his or her children in one of the central activities of their religion, such as going to church.

todial mother's First A mendment rights were not restricted when father was given custody every Sunday, during the time when she wished to take her children to church, because the order did not restrict the mother from educating her children about her religious beliefs at any other time).

50. See Zummo, 574 A .2d at 1157.

51. Some courts do refuse to issue such orders; not because the orders intrude on constitutionally protected areas of religious freedom, but because they are too great an intrusion into the visitation rights of the noncustodial parent. See B eschle, supra note 27, at 404.

52. See Johns, 918 S.W.2d at 731 (holding that because the noncustodial father was required only to bring his children to services and not to attend them himself, no limitation had been placed on his freedom of religion); B urrows, 605 A .2d at 1316 ( " [T ] he [trial court's] order did not infringe upon the mother's rights to teach her children the formal practices of the E piscopal faith... [because it] was more in the nature of an accommodation of each parent's right to inculcate religious beliefs in his or her children.").

53. See B eschle, supra note 27, at 403-04; see also In re Tisckos, 514 N.E.2d 523, 529 (III. A pp. Ct. 1987) (characterizing an order carving out a period during father's visitation in which mother has custody and control of children so that they can engage in religious activity as an "accommodation" to the mother rather than a "restriction" upon the father); Overman $v$. O verman, 497 N.E.2d 618, 619 (Ind. Ct. A pp. 1986) (finding intrusion "minimal" and stating that "custodial parent's right to choose the religious training should be paramount" and requiring that noncustodial parent transport child to weekend religious services in accordance with custodial parent's religious training program).

54. See Rinehimer, 485 A .2d at 1169 (noting that custody schedule which effectively prevents father from taking his children to religious services on Sunday mornings was designed solely in the best interests of the children, not to impinge on his religious freedom). 


\section{B. Situations in Which Parents $H$ ave an A ntenuptial A greement Regarding Their Child's R eligious U pbringing}

Courts are remarkably consistent in their refusal to effectuate antenuptial religious upbringing agreements. ${ }^{55}$ In a number of $\mathrm{N}$ ew Y ork State cases, courts have upheld the validity of religious training agreements, but only when they are part of a settlement agreement or incorporated in a divorce decree, not when they are made prior to marriage. ${ }^{56}$ The enforceability of antenuptial religious upbringing agreements becomes an issue at or after divorce, when one parent asks the court to order the other parent to raise the children in a particular faith, or to refrain from doing so, on the basis of the agreement. The requests are quite broad. They are not limited to specific religious activities, but often include demands for restrictions on religious "influence" or "indoctrination." ${ }^{57}$ Some courts facing such a request simply ignore the agreement or invalidate it without rigorous analysis. ${ }^{58} \mathrm{~A}$ number of decisions, however, indicate that the courts

55. There are a relatively small number of cases in this area. The discussion focuses on ten recent cases, from a variety of jurisdictions.

56. See Stevenot v. Stevenot, 520 N.Y.S.2d 197, 198 (N.Y. A pp. Div. 1987) (stating that "[a]n oral agreement entered into prior to and during the marital relationship is not binding upon the custodial parent following judicial dissolution of the marriage if its terms have not been reduced to a writing or included in a stipulation of settlement, divorce judgment, or custody determination" ); M ester v. M ester, 296 N.Y.S.2d 193, 198 (N.Y . Sup. Ct. 1969) (same); cf. Spring v. Glawon, 454 N.Y.S.2d 140, 142 (N.Y. A pp. Div. 1982) (noting that courts have "consistently upheld the validity of agreements as to the religious and moral training of a child," especially when confirmed by a judgment of divorce).

57. See, e.g., W eiss v. W eiss, 49 Cal. R ptr. 2d 339, 342, 346 (Cal. Ct. A pp. 1996) (refusing to grant father's request that mother be restrained from "indoctrinating" children in Christian faith or enrolling children in any activity "contrary" to Jewish faith); In re Marriage of Nuechterlein, 587 N.E.2d 21, 22 (III. A pp. Ct. 1992) (addressing noncustodial father's request that court provide for "the continuation of the religious training of the children in the L utheran faith," when parents had agreed to raise their children as L utherans); K irchner v. Caughey, 606 A .2d 257, 259 ( $M$ d. 1992) (reversing trial court order based on mother's request that father be enjoined from "all efforts to indoctrinate the child in the Baptist religion"); Schwarzman $v$. Schwarzman, 388 N.Y.S.2d 993, 994 (N.Y. Sup. Ct. 1976) (ruling against noncustodial father who sought to enjoin custodial mother from "attempting to change the religion of the infant issue of the marriage")

58. See, e.g., Sotnick v. Sotnick, 650 So. $2 d$ 157, 160 (Fla. D ist. Ct. A pp. 1995) (refusing to include parties' marital religious upbringing agreement in divorce judgment, simply stating that the great weight of legal authority is against these agreements); Stevenot, 520 N.Y .S.2d at 198 (N.Y. A pp. Div. 1987) (holding that oral premarital agreements are not binding unless their terms have been reduced to a writing following divorce or have been included in a stipulation of settlement, divorce judgment or custody determination); M acL agan v. K lein, 473 S.E .2d 778, 781 (N.C. Ct. A pp. 1996) (noting that the parents had a religious upbringing agreement that child be raised J ewish without explaining its role in the court's determination that J ewish father be responsible for child's religious training). 
believe that enforcement of such agreements, would be an unconstitutional violation of a parent's religious freedom. ${ }^{59}$

If a court refuses to recognize the validity of the agreement, it will generally resolve the issue in a manner similar to those situations in which no agreement exists. ${ }^{60}$ A parent with sole custody has the authority to direct his or her children's religious upbringing, regardless of any antenuptial agreement that specifies what the children's religious upbringing should be. ${ }^{61} \mathrm{~A}$ t the same time, the noncustodial parent also retains the right to expose the children to his or her religion during visitation, despite the existence of an antenuptial agreement regarding religious upbringing. ${ }^{62}$ If the parents have joint legal custody, they are both entitled to direct the children's religious upbringing, regardless of an antenuptial agreement determining the children's religious upbringing. ${ }^{63}$ The exercise of this right is limited only when such exposure to two religions poses a substantial threat of harm to the children's welfare. ${ }^{64}$ Courts generally remain willing to issue orders characterized as "accommodations" so that both parents

59. See, e.g., A bbo v. B riskin, 660 So. 2d 1157, 1160 (Fla. D ist. Ct. A pp. 1995) (explaining that the court order restraining mother's active religious influence over her children would interfere with the mother's own free exercise of religion); In re M arriage of B ennet, 587 N.E.2d 577, 579 (III. A pp. Ct. 1992) (engaging in formalistic contract law analysis to determine that parents did not, in fact, have an enforceable contract to raise their children in the J ewish faith, but recognizing that if their agreement was enforceable under contract law, it would still raise constitutional questions); Kirchner, $606 \mathrm{~A} .2 \mathrm{~d}$ at 260-62 (mentioning the parents' oral agreement to raise children in the Catholic faith but reversing, in part, the restriction on father's religious activities with the children as improper judicial interference with father's religious practices without discussing potential impact of the agreement); Kendall v. Kendall, 687 N.E.2d 1228, 1230 n.5 (M ass. 1997) (noting that the majority of courts find "predivorce" agreements regarding religious upbringing unenforceable on constitutional grounds, without further explanation).

60. See supra Part I.A .

61. See, e.g., N uechterlein, 587 N .E.2d at 25

62. See K irchner, 606 A .2d at 260.

63. See Sotnick, 650 So. $2 d$ at 160.

64. See, e.g., Weiss v. Weiss, 49 Cal. R ptr. 2d 339, 342-44 (Cal. Ct. A pp. 1996) (holding that without harm to the children, a court cannot restrict either parent's right to expose his or her children to religion); K endall, 687 N.E.2d at 1233 (adhering to substantial harm standard and noting that application of that requirement protects religious freedom); Schwarzman $v$. Schwarzman, 388 N.Y.S.2d 993, 998 (N.Y. Sup. Ct. 1976) (noting that parental disputes which do not cause harm to their children are beyond the reach of the law); Zummo v. Zummo, 574 A .2d 1130, 1154 (Pa. Super. Ct. 1990) (following the vast majority of courts in requiring a substantial threat of present or future, physical or emotional harm to the children in order to restrict either parent's right to provide religious exposure and instruction during periods of legal custody or visitation). 
can indoctrinate their children in the religion they choose, even when they have agreed otherwise prior to marriage. ${ }^{65}$

Few cases have provided a detailed rationale for the refusal to enforce antenuptial religious upbringing agreements, though many have made vague reference to constitutional considerations. ${ }^{66}$ In Zummo v. Zummo $0^{67}$ the court did explain its refusal to enforce such an agreement. In that case, the appellate court refused to enforce an antenuptial agreement in which a R oman Catholic father and J ewish mother agreed that any children they might have would be raised as J ews. ${ }^{68}$ The parties agreed, upon divorce, to share legal and physical custody. ${ }^{69}$ However, the mother sought and received an order from the trial court prohibiting the father from taking his children to religious services "contrary to the J ewish faith" during his periods of custody. ${ }^{70}$ The appellate court refused to enforce the agreement and vacated that portion of the order. ${ }^{11}$ It found such agreements unenforceable for three reasons: 1 ) they were too vague under standard contract principles; 2) they threatened to entangle courts in religious matters; and 3) their enforcement would be contrary to public policy principles embodied in the Free Exercise Clause: that parents be free to doubt, question and change their beliefs, and instruct their children in accordance with their beliefs. ${ }^{72}$ Similarly, in Weiss v. Weiss, ${ }^{73}$ the court refused the father's request to prohibit his former wife from "indoctrinating" their children in the Episcopalian faith during her custodial time, on the basis of their antenuptial agreement that stated that their children were to be raised as J ews. ${ }^{74}$ That court adopted the Z ummo court's rationale for its refusal to enforce the parents' an-

65. See, e.g., Weiss, 49 Cal. R ptr. $2 d$ at 342,348 (affirming order permitting father to enroll children in a religious training program regardless of his custody schedule); Zummo, $574 \mathrm{~A} .2 \mathrm{~d}$ at 1158 (ordering Catholic father to present children at J ewish Sunday school, while they are in his custody as an "accomod[ation]" to J ewish mother's right to contribute to the children's religious upbringing).

66. See supra note 59 and accompanying text.

67. 574 A .2d 1130 (Pa. Super. Ct. 1990).

68. See id. at $1145,1148$.

69. See id. at 1141

70. Id. at 1142

71. See id. at 1144

72. See id.

73. 49 Cal. R ptr. 2 d 339 (Cal. Ct. A pp. 1996).

74. See id. at 346-47. 
tenuptial agreement pertaining to the children's religious upbringing. $^{75}$

\section{JUdicial RATIONALESFOR REFUSALSto ENFORCE RELIGIOUS A NTENUPTIAL A GREEMENTS\& RESPONSESTO THEM: CONTRACT PRINCIPLES}

Those courts that find antenuptial agreements regarding religious upbringing unenforceable do so based on contract and constitutional principles. ${ }^{76}$ Courts find these agreements unenforceable under standard contract principles for two reasons: 1) they are vague and 2) they seek to bind parties over a long period of time, despite changes in marital status or religious beliefs. ${ }^{77}$

\section{A. Judicial Rationales}

U nder standard contract principles, an agreement is binding and enforceable only if the parties have agreed to be bound by it and if it contains sufficiently definite terms. ${ }^{78}$ A $n$ agreement is sufficiently definite if a court is able to examine the agreement and "fix an exact meaning upon it." ${ }^{79}$ If the terms are indefinite, the court has no objective basis upon which to force the parties to comply with the agreement, or to impose a suitable penalty should they fail to do so. ${ }^{80}$ In our hypothetical concerning Paul and Julie, both parties recognize that they made an agreement. This is true of a majority of custody

75. See id.; see also Kendall v. K endall, 687 N.E.2d 1228, 1230 n.5 (M ass. 1997) (stating that most courts agree that predivorce religious upbringing agreements are unconstitutional and therefore unenforceable).

76. See Zummo, 574 A .2d at 1144-48 (holding that such agreements are not enforceable because they are too vague to be valid contracts and because they implicate First A mendment concerns), see also, e.g., Weiss, 49 Cal. R ptr. $2 d$ at 344-47 (following Zummo court's arguments about the vagueness of such agreements and their First A mendment problems).

77. O ne court found a premarital contract concerning religious upbringing unenforceable because it lacked the formal element of an offer. See In re M arriage of B ennet, 587 N.E.2d 577, 580 (III. A pp. Ct. 1992) (finding, oddly, that respondent might have established the existence of an agreement, but could not establish an offer, without which there could be no acceptance and thus no contract).

78. Farnsworth examines contractual indefiniteness in the context of contracts concerning the purchase and sale of goods. See $1 \mathrm{E}$. A LLA N FARNSWORTH, FARNSWORTH ON CONTRACTS $\S 3.1$, at 160-61 (1990). H is discussion is relevant and applicable to the issue here as well, insofar as a court cannot enforce any agreement that fails to express what it was the parties agreed to.

79. Samuel Williston, The Law Of CONTRACTS $\S 37$ (1926) (explaining that an offer must be capable of creating a definite obligation).

80. SeeRestatement (Second) of Contracts § 33(2) (1979). 
disputes in which parents have agreed on their children's religious upbringing prior to marriage. ${ }^{81}$

While parties frequently agree on the existence of an agreement, they often disagree about its meaning. A ntenuptial agreements regarding religious upbringing are almost always vague. M ost consist of a promise, oral or written, to raise children in a particular faith. ${ }^{82}$ Most courts have found that such a promise, without more, fails to "provide an adequate basis for objective enforcement." ${ }^{83}$ For example, a promise to raise children "J ewish" fails to specify the intensity and exclusivity of religious indoctrination, to proscribe exposure to the rituals and practices of other religions, to describe a program of religious education or to explain which sect of the faith the parties intended to select. ${ }^{84}$ Thus, when one parent seeks an order restricting the other parent's religious activity with the children on the basis of such an agreement, the court has no objective basis on which to formulate such an order. The agreement gives no indication which activities the order should permit, forbid, or require. ${ }^{85}$ In most cases, the court's only option would be to order the parties to raise the children "J ewish"-an order which would have little or no meaning in terms of the specific obligations imposed. Without a more specific agreement that discusses religious education, religious services, or exposure to other religions, the court has no basis on which to issue a more specific order to the parties. Even an agreement that a child shall not attend services contrary to a particular faith is ambiguous. ${ }^{86}$ First, it does not clarify the meaning of "services." The term might be narrowly construed to include only the regular services conducted by a religious institution or more broadly, to include any activityincluding camps, dances, picnics or youth groups-sponsored by that

81. See, e.g., Weiss, $49 \mathrm{Cal}$. R ptr. $2 \mathrm{~d}$ at 341 (noting that both parents agreed that, prior to marriage, the mother had converted and signed a religious document promising to rear all children in the J ewish faith); In re M arriage of N euchterlein, 587 N.E.2d 21, 22 (III. A pp. Ct. 1992) (noting that mother and father confirmed discussion of the religious upbringing of their children and admitted agreeing that they would raise children as L utherans); K irchner v. Caughey, 606 A .2d 257, 260 ( M d. 1992) (noting that mother stated that parties had orally agreed to raise their children Catholic at children's birth); Zummo, 574 A.2d at 1145 (noting that although parents agreed prior to marriage to raise their children as J ews, they had different visions of the exclusivity and intensity of their children's J ewish education).

82. See cases cited supra note 1.

83. Zummo, 574 A .2d at 1144 .

84. See id. at 1146 .

85. See id.

86. See id. (objecting to trial court's order that father be prohibited from taking his children to "religious services contrary to the J ewish faith" (internal quotations omitted)). 
institution. A court could reasonably conclude that it was unable to issue an order prohibiting a parent from taking his children to "services," because the agreement did not indicate, in definite terms, what was meant by that phrase and because the parties could hold reasonable and different interpretations of it.

Courts have also found antenuptial religious upbringing agreements unenforceable because they were made prior to the marriage and "did not contemplate a postdivorce status." ${ }^{87}$ In doing so, courts have assumed that a couple on the verge of marriage is unable to make an informed decision regarding their potential or likely convictions about religion and childrearing after their marriage has ended. This argument suggests that because an unexpected circumstance has arisen, the contract is void upon the occurrence of that circumstance. In the context of commercial contracts, parties may be excused from performance when an unexpected contingency arises which makes their performance commercially impracticable. ${ }^{88}$ If the event was unexpected and the parties did not allocate the risk of the event in the contract and the event renders performance so difficult as to be impossible, one party may be excused from performance. ${ }^{89}$ Similarly, a court which applies the "changed circumstance" rationale appears to believe that divorce was entirely unexpected and that once divorce occurs, it renders performance so difficult (or, more accurately, so unappealing) to one of the parties that they should be excused from performance.

Finally, a court might refuse to enforce these agreements because they seek to bind parties with respect to an area of their lives which they should be free to change. As the Zummo opinion explained:

The First A mendment specifically preserves the essential religious freedom for individuals to grow, to shape, and to amend this important aspect of their lives, and the lives of their children. Religious freedom was recognized by our founding fathers to be inal-

87. Stevenot v. Stevenot, 520 N.Y.S.2d 197, 198 (N.Y. A pp. Div. 1987) (holding unenforceable an oral contract made before and reiterated during the marital relationship to raise children in the Congregational church); see also Zummo, 574 A .2d at 1147 (stating that it would be difficult for a couple to project themselves into the scenario of a divorce); Schwarzman v. Schwarzman, 388 N.Y.S.2d 993, 998 (N.Y. Sup. Ct. 1976) (stating that although mother's conversion served as evidence of agreement to raise children as Jews, the agreement "was not projected by the parties to encompass the situation presented by a divorce").

88. See 2 FARNSWORTH, supra note $78, \S 9.6$, at 543.

89. See Transatlantic Fin. Corp. v. U nited States, 363 F.2d 312, 315 (D.C. Cir. 1966). 
ienable. It remains so today. Thus, while we agree that a parent's religious freedom may yield to other compelling interests, we conclude that it may not be bargained away. ${ }^{90}$

This argument suggests that enforcement of this contract would be contrary to public policy. A court will not enforce a contract which, though facially valid, violates the Constitution. ${ }^{91}$

\section{B. Responses to R ationales for N onenforcement B ased on C ontract Principles}

1. Indefiniteness. The "indefiniteness" that often renders religious upbringing agreements unenforceable can be eliminated in most cases by the contracting parties. M any of the agreements which courts have refused to acknowledge or enforce have been oral agreements. A couple can begin, as Paul and Julie did, by putting their agreement in writing. This reduces the possibility that the couple will dispute the agreement's existence or its terms. In addition, putting the terms of their agreement in writing helps the parties to acknowledge that they are not merely discussing the issue of their children's religious upbringing, but are creating an enforceable agreement.

The written agreement must contain more than a promise to raise children in a particular faith. The parties should identify, as exhaustively and clearly as possible, all religious institutions, religious activities, religious services, religious educational institutions, and religious rituals (taking place outside the home) in which they wish their children to participate. The agreement should include a similar list of religious practices from which the parties wish their children to refrain. The agreement should cover only those practices which occur outside the home. Paul and Julie's agreement includes such an extensive list.

The agreement should also attempt to eliminate ambiguity in the terms used to describe the above-mentioned practices. Paul and Julie, for example, have agreed that their children should attend certain services at a synagogue and should not attend church services. The phrase "church services," is subject to a number of interpretations, which may lead a court to refuse to issue a broad prohibition on

90. Zummo, 574 A .2d at 1148 .

91. For a response to this argument, see infra Part III.B. 
Paul's taking his children to such services. But Paul and Julie's agreement includes a definition of that term. "Church services" include the regular religious services of any religious institution not affiliated with the J ewish faith. The term does not include weddings, funerals, and baptisms, or other similar events. Paul and Julie have also explained that certain church orchestrated gatherings, such as retreats, picnics and afterschool groups are included in their definition of church services, even when such activities take place outside the church building.

No contracting couple can entirely eliminate all ambiguity in the terms of their contract. B ut Paul and J ulie's hypothetical agreement demonstrates that it is possible to eliminate much ambiguity in antenuptial religions upbringing agreements. The agreement provides an objective basis upon which the court could issue an order both requiring or prohibiting each party from bringing their children to the activities identified.

2. Divorce as a Changed Circumstance. In the commercial context, a court may excuse nonperformance of a contract if an unexpected development arises. ${ }^{92}$ Nonperformance will be excused only if a contingency has occurred, the risk of the occurrence was not allocated either by agreement or by custom and finally, occurrence of the contingency rendered performance impracticable.$^{93} \mathrm{~A}$ number of courts that have addressed the enforceability of antenuptial religious upbringing agreements have mentioned that the agreement did not anticipate the possibility of divorce. ${ }^{94} \mathrm{~A} s$ a result, courts indicate that divorce is a changed circumstance which renders such an agreement unenforceable. O ne court has described divorce as an "unconsidered possibility." ${ }^{95}$

Prospective parents who wish their contract to apply in the event of a divorce should simply state this intention in their agreement. In so doing, the parties explicitly acknowledge that their circumstances may change, and they affirm their commitment to their agreement, whatever the state of their marriage. A ntenuptial contracts which

92. See, e.g., Transatlantic Fin. Corp., 363 F.2d at 315 (explaining the doctrine of impossibility of performance based on unexpected events).

93. See id.; see also 2 FARNSWORTH, supra note 78 , § 9.6, at 543-58 (explaining the four elements of impracticability, one of which is that the party seeking to be excused did not promise to perform, even in the event that performance became impracticable).

94. See supra note 87 and accompanying text.

95. Zummo, 574 A .2d at 1147 . 
specifically provide for property distribution upon divorce are routinely enforced by courts, even if that agreement ceases to appeal to one of the parties at that time. ${ }^{96}$ A s one court has explained "everyone knows that circumstances can change ... so that what initially appeared desirable might prove to be an unfavorable bargain." ${ }^{97}$ If the parties agree explicitly that their agreement outlasts divorce, divorce ought not be viewed as a changed circumstance excusing one party from performance.

Despite the claim that couples entering into such agreements "generally will not be able to anticipate the fundamental changes in circumstances between their prenuptial optimism, their struggles for accommodation and their ultimate post-divorce disillusionment," ${ }^{98} \mathrm{a}$ couple who feels able to do so and wishes to bind themselves to a particular religious upbringing for their children, despite the possibility of divorce, should be able to do so. The agreement's very purpose is to protect each party from the risk that either will change their mind. That risk is even greater upon divorce. If parties wish to protect themselves against such a circumstance, they should be able to do so by contract. Paul and J ulie have included a phrase in their agreement, evidencing their contemplation of a possible divorce. Where the parties have clearly evidenced an intention for the agreement to apply even after a divorce, no court should find the agreement unenforceable for failure to contemplate a post-divorce status.

96. See L aura P. G raham, Comment, The U niform Premarital A greement A ct and M odern Social Policy: The Enforceability of Premarital A greements Regulating the $O$ ngoing $M$ arriage, 28 WA KE FOREST L. REV. 1037, 1040 (1993) (noting that following the passage of the M arried Women's Property A cts in many states, state courts routinely upheld provisions within premarital contracts which allocated property upon divorce). A ntenuptial agreements must satisfy local tests of procedural and substantive fairness, however, if they are to be upheld. See J udith T. Y ounger, Perspectives on A ntenuptial A greements: An Update, $8 \mathrm{~J}$. A M. A CAD. MATRIM. LA W. 1, 18 (1992).

97. Simeone v. Simeone, 581 A .2d 162, 166 (Pa. 1990) (refusing to excuse parties from prenuptial agreement regarding property at divorce and arguing that excuse had been based on the outdated assumption that women are not knowledgeable enough to understand the nature of the contracts that they enter).

98. Zummo, 574 A .2d at 1147. 


\section{JUdiCIALRATIONALESFOR NONENFORCEMENT \& RESPONSES: CONSTITUTIONAL PRINCIPLES}

\section{A. Judicial Rationales}

Those courts that have discussed the enforceability of antenuptial religious upbringing agreements find that enforcement would violate the Free E stablishment and Free E xercise Clauses of the First A mendment. ${ }^{99}$ For example, enforcement might involve an order prohibiting a parent from bringing a child to church, or requiring a parent to raise a child

in the Jewish faith. This would violate the general rule that "'constitutionally, A merican courts are forbidden from interfering with religious freedoms or... preferring one religion over another."'100

The majority of decisions in which courts refuse to enforce antenuptial religious upbringing agreements suggest that enforcement would be unconstitutional. ${ }^{101}$ One interpretation of the Zummo opinion suggests a tri-fold constitutional rubric for analyzing these agreements: ${ }^{102}$ first, that enforcement will "entangle" courts in matters of religious doctrine; second, that enforcement will require ongoing observation of and involvement with a family's religious activities (a type of administrative entanglement); and third, that enforcement requires interference with each parent's right to freely exercise his or her religion and to share that religion with his or her children. ${ }^{103}$ The first two concerns fall under the Establishment

99. The First A mendment to the Constitution provides that "Congress shall make no law respecting an establishment of religion, or prohibiting the free exercise thereof." U.S. CONST. amend. I. This amendment applies to the states through the Fourteenth A mendment. See Cantwell v. Connecticut, 310 U .S. 296, 303 (1940). It applies to judicial as well as legislative action. See N A A CP v. A labama, 357 U.S. 449, 463 (1958); see also Zummo, 574 A .2d at 1144 (explaining that enforcement of antenuptial religious upbringing agreements would be contrary to the $\mathrm{E}$ stablishment and Free E xercise Clauses of the First A mendment).

100. Kirchner v. Caughey, 606 A .2d 257, 262 (M d. 1992) (quoting M unoz v. M unoz, 489 P.2d 1133, 1135 (W ash. 1971)).

101. See supra note 59 and accompanying text.

102. See Zummo, 574 A .2d at 1144.

103. Seeid. 
Clause of the First A mendment, ${ }^{104}$ the third under the Free Exercise Clause. ${ }^{105}$

1. Doctrinal Entanglement. The Supreme Court has not addressed the constitutional implications of enforcing an antenuptial religious upbringing agreement, and there is no controlling federal authority on that issue. However, the Court's cases establish that civil courts cannot resolve questions of religious doctrine as that would involve courts in religious matters in a manner forbidden by the Establishment Clause. ${ }^{106}$ This prohibition arose from an early case in which a civil court was asked to determine which of two rival factions of a church espoused the appropriate church teachings, in order to resolve a property dispute. ${ }^{107}$ There, the Supreme Court held that to involve civil courts in core matters of religious belief and ritual would destroy the autonomy of religious institutions and thereby subvert fundamental First A mendment values. ${ }^{108}$

Later cases have recognized that the prohibition against doctrinal entanglement reflects a more fundamental concern about the government's appropriate role in religious matters. ${ }^{109}$ N ot only does the prohibition seek to preserve the autonomy of religious institutions, it recognizes that neither the courts nor the legislative and executive branches can "prescribe what shall be orthodox in politics, nationalism [or] religion." 110 H owever, courts are not precluded from resolving a dispute simply because it involves a religious organization. If neutral principles of law apply to the dispute and the court

104. See La Wrence Tribe, A merican Constitutional La w 1226-27 (1988) (discussing five First $A$ mendment doctrines based on the undesirability of excessive church-state entanglement).

105. See Zummo, 574 A .2d at 1146.

106. See M arshall, Comment, supra note 45 , at 249-53. See generally M ichael William Galligan, Note, Judicial Resolution of Intrachurch Disputes, 83 CoLUM. L. REV. 2007 (1983) (analyzing two approaches to judicial resolution of intrachurch disputes and advocating universal adoption of the rule of neutral principles).

107. See W atson v. J ones, 80 U .S. ( 13 W all.) 679, 727 (1871) (pronouncing an ecclesiastical judgment final in a property dispute between two Presbyterian factions).

108. See id. at 729; see also Presbyterian Church v. Mary Elizabeth Blue Hull M em'l Presbyterian Church, 393 U.S. 440, 450 (1969) (holding that civil courts could not resolve a property dispute which turned on whether a national church's actions were a substantial departure from its original tenets of faith and practice).

109. See TRIBE, supra note 104 , at 1231.

110. West V irginia State B d. of E duc. v. B arnette, 319 U .S. 624, 642 (1943). 
need not "rely on religious precepts... [or] resolve a religious controversy," the court may resolve the dispute. ${ }^{111}$

The nature of a religious upbringing is certainly a question of religious doctrine. A s a preliminary question, a court asked to enforce an agreement must identify which sect of a particular faith the parties intended to select. If, for example, the parties have made only a vague promise to raise the children in the Jewish faith, a court will have no basis on which to determine what that means. ${ }^{112}$ The J ewish faith includes a number of sects, among them Orthodox, Conservative and Reform, all of which may differ as to the meaning of the J ewish faith ${ }^{113}$ E ven within a particular sect, individuals may differ as to what activities, rituals or education a particular faith requires. It is difficult to imagine a court resolving these questions without investigating the requirements, rituals, and beliefs held by different religions or different sects within one religion. Even a more specific agreement, stating that a child will not attend any religious services "contrary" to a particular faith would require the court to determine what a religious service is, and what services are contrary. A gain, such a question requires a court to make judgments about religious doctrine that the E stablishment Clause forbids. ${ }^{114}$ Thus a court could refuse to order a parent to comply with a religious upbringing agreement as "the subject matter and the ambiguities of the order make excessive entanglement in religious matters inevitable if the order is to be enforced." ${ }^{115}$

2. Excessive Administrative Entanglement. Enforcement of antenuptial agreements regarding religious upbringing also threatens to involve the court in religious matters, not simply from a doctrinal, but also from an administrative perspective, in a manner forbidden by the Establishment Clause. While a number of cases in which courts decline to enforce religious upbringing agreements refer

111. J ones v. Wolf, 443 U.S. 595, 604 (1979) (holding that a civil court could resolve a church property dispute where church documents contained secular language upon which the court could resolve the dispute, without considering matters of religious doctrine).

112. See Weiss v. Weiss, 49 Cal. R ptr. 2d 339, 341 (Cal. Ct. A pp. 1996); Sotnick v. Sotnick, 650 So. 2d 157, 159 (Fla. Dist. Ct. A pp. 1995); Zummo v. Zummo, 574 A .2d 1130, 1141, 1144 (Pa. Super. Ct. 1990).

113. Seejudy Petsonk \& JIM RemSen, The IntermarRIAge Handbook 277-86, 334-79 (1988) (discussing the various J ewish sects and their positions on religious education and upbringing).

114. See supra notes $106-11$ and accompanying text.

115. Zummo, 574 A .2d at 1146. 
generally to the E stablishment Clause, ${ }_{1}^{116}$ Zummo explicitly relies on Lemon v. Kurtzman, which established a three-part test for Establishment Clause claims. ${ }^{117}$ This three-part inquiry examines government involvement with religion to determine if it has: 1) a secular legislative purpose; 2) a principal or primary effect that neither advances nor inhibits religion; and 3 ) if it avoids fostering an excessive government entanglement with religion. ${ }^{118}$

L emon invalidated two state statutes providing aid to churchrelated elementary schools based on the third prong of the test. ${ }^{119}$ The Court held that the "cumulative impact of the entire relationship" arising under the statutes in the relevant state was one of excessive entanglement between government and religion. ${ }^{120}$ The program established by the statutes required continuing state oversight of the religious content of classes taught by a religious organization. ${ }^{121}$ The Court deemed that involvement excessive. ${ }^{122}$ By contrast, in J immy Swaggart Ministries v. Board of Equalization, ${ }_{12}^{23}$ the Court affirmed the constitutionality of the application of a sales and use tax to religious materials. ${ }^{124}$ As that statutory scheme did not implicate state employees in, or oversight of, appellants' day to day operations, the statute in question did not foster an excessive government entangle-

116. See A bbo v. Briskin, 660 So. 2 d 1157, 1159 (Fla. D ist. Ct. A pp. 1995) (noting that the $\mathrm{Bill}$ of R ights bars the government from establishing or supporting any particular religion); In re M arriage of B ennet, 587 N.E.2d 577, 579 (III. A pp. Ct. 1992) (noting that the trial court had concluded that enforcement of an antenuptial religious upbringing agreement would violate the Establishment Clause, but declining to reach that issue after finding that no such agreement existed); K irchner v. Caughey, 606 A .2d 257, 261 (M d. 1992) (explaining courts' reluctance to interfere with religious faith and training of children as constitutionally forbidden interference with or preference for religion).

117. See Zummo, 574 A .2d at 1146 (citing L emon v. K urtzman, 403 U .S. 602, 613 (1971)).

118. See L emon, 403 U.S. at 612-13. Several years earlier, in School District of A bington Township v. Schempp, 374 U .S. 203, 222 (1963), the Supreme Court had established a two-part test for Establishment Clause claims several years earlier: 1 ) whether a statute had the purpose or 2) primary effect of advancing religion. In L emon, the Court found that two-part test inadequate and added the third prong, which asks whether a statute fosters an excessive government entanglement with religion. See L emon, $403 \cup$.S. at 612-13. The first two prongs of the L emon test are not particularly useful in assessing the constitutionality of religious upbringing agreements, as no court has refused to enforce them because they have the purpose or effect of advancing religion.

119. See L emon, 403 U .S. at $613-14$

120. Id. at 614.

121. See id. at $619,620-21$.

122. Seeid.

123. 493 U .S. 378 (1990).

124. See id. at 392 . 
ment with religion. ${ }^{125}$ Zummo also focused on the third prong, and asked whether the government action involved an "excessive entanglement" with religion, and found that it did. ${ }^{126}$

The Lemon test has been sharply criticized in recent years. ${ }^{127}$ The Court has offered other Establishment Clause tests, which have been termed the "endorsement" test ${ }^{128}$ or the "coercion" test ${ }^{129}$ and sometimes ignored the Lemon test entirely. ${ }^{130} \mathrm{Y}$ et it has never rejected that test in a majority opinion. ${ }^{131}$ A t present, it is not clear what role the third prong of Lemon plays in Establishment Clause analysis, as a number of decisions have suggested that the first two prongs, purpose and effect, are of primary importance. ${ }^{132}$ In a recent case, A gostini v. Felton, ${ }^{133}$ however, the Court noted that it had considered "entanglement" as a factor in its assessment of the constitutionality of a state aid program in which public school teachers enter parochial school classrooms to teach secular remedial and enrichment classes. ${ }^{134}$ The Court raised the possibility that pervasive moni-

125. See id. at 394; cf. Tilton v. Richardson, 403 U .S. 672, 688 (1971) (holding that a single purpose, one-time construction grant from the government to a college, with no continuing financial relationship or governmental analysis of the institution's expenditures on secular, as distinguished from religious, activities did not constitute entanglement in violation of the $\mathrm{Es}$ tablishment Clause).

126. See Zummo v. Zummo, 574 A .2d 1130, 1146 (Pa. Super. Ct. 1990) (citing L emon, 403 U.S. at 613).

127. See Board of E duc. v. G rumet, 512 U .S. 687, 721 (1994) (O 'Connor, J., concurring) (advocating the liberation of case law from "the $L$ emon test's rigid influence"); $L$ amb's Chapel v. Center M oriches U nion Free Sch. Dist., 508 U.S. 384, 398 (1993) (noting that "[0]ver the years ... no fewer than five of the currently sitting J ustices have, in their own opinions, personally driven pencils through [L emon's] heart"); Lee v. Weisman, 505 U.S. 577, 644 (1992) (Scalia, J., dissenting) (describing Lemon as a "formulaic abstraction ... which has received well-earned criticism from many M embers of this Court").

128. See, e.g., L ynch v. D onnelly, 465 U .S. 668, 687-92 (1984) (0 'Connor, J., concurring) (explaining the endorsement test, which incorporates the purpose and effect prongs of $L$ emon).

129. See L ee, 505 U.S. at 599 (holding that a governmental entity may not "persuade or compel [someone] to participate in a religious exercise").

130. See id. at 644. The majority in L ee held, without applying L emon, that a school cannot conduct religious exercises at a graduation ceremony in circumstances where "young graduates who object are induced to conform." Id. at 599.

131. See id. at 603 n.4 (Blackmun, J ., concurring) (noting that, between 1971 and 1992, the Court decided $31 \mathrm{E}$ stablishment Clause cases and rested its decision in all but one of these on the basic principles described in $\mathrm{L}$ emon).

132. See A guilar v. Felton, 473 U .S. 402, 430 (1985) (O 'Connor, J ., dissenting).

133. 117 S. Ct. 1997 (1997).

134. See id. at 2016 (noting that the Court's three primary criteria for determining whether government actions aid religion are whether: 1 ) the aid results in "governmental indoctrination;" 2) recipients are defined by reference to religion; or 3 ) the aid creates an excessive entanglement). 
toring of public school teachers, to screen for inculcation of religion in students, could amount to excessive entanglement but held that no such monitoring was required in this case. ${ }^{135}$ Thus the court indicated that entanglement is still a factor. In any case, the question of excessive government entanglement with religion remains relevant to the constitutionality of requests that a court prohibit one parent from indoctrinating a child in religion, or restrain one parent from attending church services with his or her children. ${ }^{136}$ Such orders may require an ongoing government supervision of religious activity that could impermissibly involve the court in religious matters. ${ }^{137}$

Courts may become entangled in religious matters if, on the basis of an antenuptial religious upbringing agreement, they issue orders restricting one parent's religious activities with his or her children. The agreement's "subject matter... make[s] excessive entanglement in religious matters inevitable if the order is to be enforced." ${ }^{138}$ The order, as a form of ongoing governmental supervision of religious activity, might be considered "excessive entanglement" with religion and therefore violates the First A mendment. Moreover, as entanglement is a matter of concern to state courts, it must be addressed in any discussion of the enforceability of religious upbringing agreements.

3. Constitutional Implications of R estricting Free Exercise Rights in the Context of a Familial Relationship. Family relationships, including parental rights of custody and control over minor children, are constitutionally protected from unreasonable state intervention. ${ }^{139}$ Parents have a constitutionally protected right to control the education of their children. ${ }^{140}$ When the familial structure is shattered by divorce, each parent retains a protected interest in authority over

135. See id. at 2015-16.

136. See supra note 94 and accompanying text

137. See N ote, supra note 25 , at 1726 n. 79 (explaining that judicial enforcement of religious upbringing agreements threatens to violate the E stablishment Clause as "it entangles the court with religion by requiring it to supervise the child's religious training continually"). The author argues against any attempt to control a child's religious upbringing after a custody order, for "state intervention and supervision to control religious upbringing violates the independence of church and state." Id.

138. Zummo v. Zummo, 574 A .2d 1130, 1146 (Pa. Super. Ct. 1990).

139. See $M$ angrum, supra note 24 , at 44 .

140. See, e.g., Pierce v. Society of Sisters, 268 U .S. 510, 534-35 (1925); M eyer v. N ebraska, 262 U.S. 390, 399-402 (1923). 
his or her children. ${ }^{141}$ The early cases which established that right did so on grounds of substantive due process and parental rights, not religious freedom. ${ }^{142} \mathrm{H}$ owever, they did involve, in part, the parental right to control the religious upbringing of children. ${ }^{143}$

In Wisconsin v. Yoder, ${ }^{144}$ the Court specifically recognized that parents have a constitutionally protected right to control the religious upbringing of their children. ${ }^{145}$ Y oder established that the Free Exercise clause provides an additional basis for protecting familial autonomy against state intervention, in matters of familial and religious significance. ${ }^{146}$ More recently, this right has been described as a "hybrid," a free exercise claim that is connected to the rights of parents to direct the education of their children. ${ }^{147}$ In cases involving such hybrid rights, the Court has held that the First A mendment bars application of neutral, generally applicable laws to protected conduct, in the absence of a compelling state interest. ${ }^{148}$

141. See Developments in the Law-The Constitution and the Family, 93 HARV. L. REV. 1156, 1328 (1980) [hereinafter The Constitution and the Family].

142. See Meyer, 262 U.S. at 399 (noting that the liberties guaranteed by the Fourteenth A mendment include "the right of the individual to ... marry, establish a home and bring up children, [and] to worship G od according to the dictates of his own conscience"). In Pierce, the Supreme Court held that

the A ct of 1922 unreasonably interferes with the liberty of parents and guardians to protect the upbringing and education of children under their control.... The child is not the mere creature of the State; those who nurture him and direct his destiny have the right, coupled with the high duty, to recognize and prepare him for additional obligations.

268 U.S. at 534-35.

143. See Pierce, 268 U.S. at 532 (invalidating an O regon compulsory public school education law, on the basis that the statute unlawfully interfered with parental rights to choose schools "where the children will receive appropriate mental and religious training").

144. 406 U .S. 205 (1972)

145. See id. at 232.

146. Seeid.

147. See Employment Div. v. Smith, 494 U S. 872, 882 (1990) (discussing the nature of "hybrid" rights, generally involving a free exercise claim linked to either a communicative or parental right).

148. See id. at 881 (noting that "the only decisions in which we have held that the First A mendment bars application of a neutral, generally applicable law to religiously motivated action have involved not the Free Exercise Clause alone, but the Free Exercise Clause in conjunction with other constitutional protections, such as ... the rights of parents"). E mployment Division v. Smith broke with Supreme Court precedent in rejecting the compelling interest test as the standard for determining whether government action that substantially burdens religious practice violates the Free Exercise Clause, even in contexts which do not involve a hybrid right. Instead, the Court held that a neutral, generally applicable law that incidentally burdens religion, even if that burden is substantial, does not require a compelling government interest, at least in the criminal context. See id. at 884-87. Congress responded by enacting the R eligious Freedom R estoration A ct, intended to re-establish the compelling interest test for Free Exer- 
Specifically, Wisconsin v. Yoder noted that the parental right to control the religious upbringing of children may be subject to limitation if "it appears that decisions will jeopardize the health or safety of the child[ren], or have a potential for significant social burdens." ${ }^{149}$ Thus the state has a substantial burden to meet in demonstrating an interest of sufficient magnitude to override parental rights to control the religious upbringing of children. ${ }^{150} \mathrm{Y}$ oder focused on the rights of the state as compared to the rights of parents; it did not address the rights of one parent as compared to the other parent, in directing a child's religious education.

O ne court, refusing to justify restrictions on a parent's right to direct his or her children's religious education has stated that:

each parent must be free to provide religious exposure and instruction, as that parent sees fit, during any and all period of legal custody or visitation without restriction, unless the challenged beliefs or conduct of the parent are demonstrated to present a substantial threat of present or future, physical or emotional harm to the child[ren] in absence of the proposed restriction. ${ }^{151}$

If a court seeks to impose a restriction on a parent's ability to control his or her child's religious upbringing, that restriction must be justified by a compelling interest. That "interest" will generally be present only when there is a threat of harm to the children. ${ }^{152} \mathrm{H}$ aving concluded that such a standard must be met, courts have attached little significance to the parents' decision to curtail their own Free Exercise rights by entering into an agreement to give their children a particular religious upbringing. ${ }^{153}$ In Zummo, the court simply concluded that as "[r]eligious freedom was recognized by our founding

cise Claims. See 42 U .S.C. § 2000bb(b) (1994) ("The purposes of this Chapter are-(1) to restore the compelling interest test ... and to guarantee its application in all cases where free exercise of religion is substantially burdened."). The Supreme Court recently found the A ct unconstitutional. See City of B oerne v. Flores, 117 S. Ct. 2157, 2160 (1997).

149. Yoder, 406 U .S. at 234.

150. In J ehovah's Witnesses v. K ing County H ospital, the Supreme Court affirmed a district court ruling requiring that children be declared wards of the state for the purpose of obtaining emergency blood transfusions that the parents would deny based on their religious beliefs. See 390 U .S. 598, 598 (1968), aff'g 278 F. Supp. 488, 503-05 (W.D. Wash. 1967). The district court found that the children were in mortal danger, see $278 \mathrm{~F}$. Supp. at $503 \& \mathrm{n} .10$, but warned that not every state intervention to protect the health and welfare of the children would withstand constitutional scrutiny. See id. at 504.

151. Zummo v. Z ummo, 574 A .2d 1130, 1154-55 (Pa. Super. Ct. 1990).

152. See supra notes $28-30$ and accompanying text.

153. See supra Part I.B. 
fathers to be inalienable, i[t] remains so today. Thus, while we agree that a parent's religious freedom may yield to other compelling interests, we conclude that it may not be bargained away. ${ }^{154}$

\section{B. Responses}

1. D octrinal D eterminations. Vagueness poses a constitutional, as well as contractual, barrier to judicial enforcement of antenuptial religious upbringing agreements. J ust as the parties can eliminate indefiniteness by careful drafting, they can also eliminate the vagueness which would require a court to determine the content of a religious upbringing in a particular faith. ${ }^{155}$ If the agreement clearly identified and defined the rituals, activities and religious services in which the parties want their children to participate, the court need not investigate matters of religious doctrine for the purposes of issuing an order based on that agreement. ${ }^{156}$ Paul and Julie's agreement serves this purpose. It does not require the court to look beyond the activities identified or to make any determinations deemed "doctrinal." A court need not be familiar with a Christian or J ewish concept of a child's religious upbringing to order each parent to bring (and to refrain from bringing) his or her children to the activities, services, and schools set forth in the agreement.

2. Administrative Entanglement. Judicial enforcement of a private agreement that sets forth in precise terms the course of children's religious upbringing does not impermissibly entangle the court in religious matters, in violation of the Establishment Clause. First, the act of contractual interpretation and enforcement does not present an E stablishment Clause problem. The subject matter of the contract involves religious activities and the contracting parties constitute a family, which enjoys constitutional protection from state interference. But a court is not constitutionally prohibited from resolving this dispute, if it can use neutral principles of contract law to do so. For example, in the context of intrachurch property disputes, the Supreme Court has held that when neutral principles of

154. Zummo, 574 A .2d at 1148 (emphasis omitted).

155. See supra notes 78-86 and accompanying text (discussing the difficulties encountered by courts attempting to interpret and enforce vague agreements).

156. See supra notes 106-15 and accompanying text (discussing problems that arise when agreements are not drafted with sufficient specificity). 
law apply to a dispute among members of a church, involving church property, a court can use those principles to resolve the dispute. ${ }^{157}$ The affected party in those cases is a constitutionally protected entity, but a court can apply neutral legal principles to resolve a dispute within that entity, without violating the Establishment Clause. ${ }^{158}$ This is true even though in doing so, the court "will either support or overturn the [church authority's] resolution of the dispute," and thereby indirectly interfere with that authority. ${ }^{159}$ A family which has bound itself by civil contract to a certain course of action and subsequently disagrees about that course of action should similarly be able to have their contract enforced, based upon neutral concepts of civil contract law, even if that contract touches on religious matters. ${ }^{160}$ The parties have bound themselves by contract, that contract imposes rights and obligations; policing adherence to contractual obligations is a matter that appropriately falls under the authority of civil courts. ${ }^{161}$

E nforcement of an order based on the agreement may involve a court in some oversight of religious matters, which has been deemed impermissible under the Establishment Clause in certain circumstances. ${ }^{162}$ Enforcement of a highly specific and detailed contract, however, reduces the judicial oversight required. A court order restricting a noncustodial parent from "indoctrinating" his or her children in religious matters or one restraining a custodial parent from "raising" his or her children in a particular faith would require continuous, ongoing inspection of all activities, discussions and interactions between parent and children. This would clearly violate the E s-

157. See J ones v. W olf, 443 U .S. 595, 603-04 (1979) (explaining that the "neutral-principles" approach "relies exclusively on objective, well-established [legal] concepts ... familiar to lawyers and judges" and thus "promises to free civil courts completely from entanglement in questions of religious doctrine, polity, and practice").

158. See id. at 604.

159. See id. at 614 (Powell, J., dissenting).

160. See, e.g., A vitzur v. A vitzur, 446 N.E.2d 136, 137-39, (N.Y. 1983) (enforcing a provision of a J ewish marriage contract or "K etubah," whereby husband promised he would appear before a religious tribunal known as a "Beth $D$ in," for the purpose of obtaining a religious divorce and characterizing the obligation incurred by the husband as "secular" although the "B eth $D$ in" is a religious body).

161. Cf. Galligan, supra note 106, at 2026 (noting that whatever problems there may be in adjudicating intrachurch disputes, there is no justification for immunizing churches from responsibilities that all other associations bear to respect contractual rights of their members).

162. See supra Part III.A.1-2. 
tablishment Clause. ${ }^{163} \mathrm{H}$ owever, a contract which simply requires the children to participate in certain religious activities outside the home and not to participate in others could be enforced with a fairly low level of supervision. The court would simply order that on certain days, the children attend religious school or religious activities as the parents agreed, and not participate in those activities prohibited by the contract. The level of oversight required to enforce that order is no greater than that already assumed by courts in a number of custody decisions.

In resolving custody disputes where religion is at issue, courts do issue and enforce orders that concern religious matters. If, for example, a court orders a Catholic father to bring his children to synagogue, at the request of the J ewish mother during his visitation time, the court is making an order whose enforcement requires some ongoing judicial supervision of religious matters. ${ }^{164}$ If a court orders a custodial Catholic mother to send her children to an afterschool $\mathrm{He}$ brew school at the request of the Jewish father, ${ }^{165}$ that too requires ongoing supervision of religious matters. If a court orders a noncustodial parent who does not practice religion to bring his children to Sunday school and church services during his hours of visitation at the custodial parent's request, ${ }^{166}$ it involves itself in religious matters. In all cases, to enforce the order, the court will be required to engage in ongoing supervision to ensure that a parent fulfills obligations imposed by the court, obligations which are related to religion.

L ooking simply at the issue of state involvement with religion, then, it is no greater when a court orders a parent to deliver his or her children to church on the basis of a contract than it is when based on a request of the other parent. ${ }^{167} \mathrm{~N}$ or is the state involvement with re-

163. See supra notes $116-31$ and accompanying text (discussing tests for validity of actions under the E stablishment Clause).

164. See, e.g., Zummo v. Zummo, 574 A .2d 1130, 1157-58 (Pa. Super. Ct. 1990) (ordering noncustodial Catholic father to bring children to synagogue for Sunday school, in accordance with mother's program of religious training, during his visitation time).

165. See, e.g., Grayman v. Hession, 446 N.Y.S.2d 505, 506 (N.Y. A pp. Div. 1982) (upholding such an order).

166. See, e.g., J ohns v. J ohns, 918 S.W.2d 728, 729-31 (A rk. Ct. A pp. 1996) (upholding such an order).

167. A Iso, it should be noted that in no case is the court expressing a preference for one religion over another. A court that acts to protect children, to enforce a contract, or to accommodate another parent acts with neutrality toward religious matters. Cf. B eschle, supra note 27, at 421-22 (stating that when the court acts to further the custodial parent's right to control the children's religious education or to prevent confusion in the mind of the children, neither goal appears invalid under the L emon purpose and effect analysis). 
ligion any greater when the court orders a parent to refrain from bringing his or her children to church. ${ }^{168}$ The ongoing supervision concern posed by the third prong of the Lemon test does not require courts to ignore religious upbringing agreements, as courts already involve themselves in such supervision. Moreover, a highly specific contract, such as Paul and Julie's, reduces the oversight required by the court.

The Z ummo opinion indicates that the E stablishment Clause requires "benign neutrality" towards both parent's religious viewpoints. ${ }^{169}$ A court can maintain its neutrality toward religion while enforcing a contract that relates to religious matters. A s the Supreme Court has said in the context of civil court adjudication of church property disputes:

[T ] he neutral-principles approach . . . is completely secular in operation, and yet flexible enough to accommodate all forms of religious organization and polity. The method relies exclusively on objective, well-established concepts of ... law familiar to lawyers and judges.... Furthermore, the neutral-principles analysis shares the peculiar genius of private-law systems in general-flexibility in ordering private rights and obligations to reflect the intentions of the parties. ${ }^{170}$

Judicial enforcement of a contract seeks simply to determine what the parties agreed. It does not seek to frustrate either party's religious views, even when it touches on religious matters, it simply requires them to behave in accordance with the contract. ${ }^{171}$ It does not involve the court in choosing or favoring one religion over another, as that has already been done by the parties.

3. The Free Exercise Clause. Parents enjoy a constitutionally protected right to practice any religion they choose and to expose

168. I am not suggesting that the two situations are comparable for the purposes of analysis under the Free Exercise Clause. See infra notes 172-73 and accompanying text.

169. See Zummo, 574 A .2d at 1157-58 (defending the constitutionality of orders specifically designed to ensure each parent's ability to expose his or her children to religious services or activities).

170. J ones v. Wolf, 443 U.S. 595, 603 (1979).

171. Cf. A vitzur v. A vitzur, 446 N.E.2d 136, 138 (N.Y. 1983) (finding neutral principles of contract law applicable to a contract between a husband and wife, with respect to a provision requiring parties to recognize a religious tribunal to settle their marital disputes and that the contract dispute could be resolved, and the husband ordered before the tribunal, without involving the court in religion). 
their children to that religion. ${ }^{172}$ Enforcement of antenuptial religious upbringing agreements need not interfere with the parent's right, as an individual, to practice religion freely. A broad restriction against indoctrinating or influencing one's children with respect to religious matters would interfere with that right. A parent subject to such a restriction would be unable to speak about religion with the children, to pray in front of the children, to adorn his or her home with religious symbols or to engage in an infinite number of activities that might "influence" the children with respect to religion. A t all times that the parent was in the presence of the children, the parent would be unable to practice his or her religion. ${ }^{173}$

A $\mathrm{n}$ order requiring the children's attendance at certain religious activities and prohibiting the children's attendance at the religious activities of another faith (all of which occur outside the home), however, need not interfere with the parent's free exercise rights. A court could issue such an order based on an agreement like Paul and Julie's. If Paul was subject to such an order, he would still be free to discuss religion with his children, to celebrate Christmas and E aster in his home with them and to pray in their company.

Paul would not, however, be allowed to take his children to church. While this restriction need not impact his individual right to practice religion, it does impact his right to contribute to the religious upbringing of his children. That right, as a general matter, enjoys constitutional protection, and burdens upon it are subject to a particularly high level of scrutiny. ${ }^{174}$ However, interference with that right is constitutionally permissible in this context. First, those cases which protect a parent's right to the religious upbringing of their children arose in the context of a dispute between the state and the family, not a dispute between a mother and a father. ${ }^{175} \mathrm{~W}$ isconsin's compulsory school attendance law, at issue in Wisconsin v. Yoder, involved "the fundamental interests of parents, as contrasted with that of the State, to guide the religious future and education of their child." ${ }^{176}$ The Court held that such a law could only be justified "if it

172. See supra notes $144-48$ and accompanying text.

173. See, e.g., A bbo v. B riskin, 660 So. $2 d$ 1157, 1157-60 (holding that the trial court, ordering a Catholic custodial mother to raise her child in the noncustodial parent's faith and to refrain from actively influencing the child inconsistently with that faith threatened mother's right to freely exercise her own religion in her home).

174. See supra notes $148-52$ and accompanying text.

175. See supra notes $140-48$ and accompanying text.

176. Yoder, 406 U .S. 205, 232 (1972). 
appears that parental decisions will jeopardize the health or safety of the children." 177

The principle that a family, or even a divorced parent, has the right to control the upbringing of children free from state interference does not govern the question present here. A s between Paul and Julie, who has the right to control their children's religious upbringing? ${ }^{178} \mathrm{H}$ ow is the court to decide between them? A s one commentator has explained, the state ordinarily defers to parental decisions in the area of religious upbringing. H owever,

[W ]hen divorcing parents disagree about their children's religious status, these arguments apply equally to both parents' preferences. A nd we have no basis for deciding which parent's interests to prefer. The interests are the same interests. The two parents have the same claim to advance those interests.... To put the point crudely, the two rights cancelled each other. ${ }^{179}$

Custody disputes are unique in that judicial involvement is required. ${ }^{180}$ In Wisconsin v. Y oder, the family was freed from the state's attempt to direct its children's education and thus impact the religious training that the parents sought to provide, ${ }^{181}$ but custody cases present a different scenario.

Courts faced with a custody dispute must resolve it. ${ }^{182}$ When that dispute involves religious issues, any solution the court devises will interfere with both parents' right to control their children's religious upbringing. The family has that right as an entity, but upon divorce that entity has split, and, in this case, disagrees on this particular issue. If each parent seeks to raise the children exclusively in one religion, a court inevitably infringes on one, if not both, parent's right to direct the children's religious upbringing. O ne parent must be

177. Id. at 233-34.

178. That is assuming that neither Paul nor J ulie's religious practices would cause substantial harm and thus require state intervention to protect the children and that neither's approach to religion is clearly in the best interests of the children. See id. at 234 (explaining that parental rights may be limited if parental decisions will jeopardize the health or safety of the children).

179. Schneider, supra note 40 , at 885 .

180. See Steven M . Zarowny, N ote, The Religious U pbringing of Children A fter D ivorce, 56 Notre DAME L. ReV. 160, 164 (1980) (noting that "child custody contests necessitate state mediation to determine which parent will be chiefly responsible for raising the child").

181. See Y oder, 406 U .S. at 234-36.

182. See The Constitution and the Family, supra note 141, at 1326 (explaining that in contested custody cases, state intervention in itself does not infringe upon the right of family autonomy, as the state is "thrust into the role of mediator by necessity"). 
given that right, or each parent may be allowed to direct the children's religious upbringing during the time he or she spends with them. B oth solutions, even the second, which appears to honor both parent's rights, will infringe on the rights of that parent who believes that to direct a child's religious upbringing is to raise them exclusively in one religion. A s this is so, the most justifiable infringement is that which the parties have chosen for themselves, rather than that which the court imposes upon them. Thus the court should rely on the parties' own agreement, when they dispute the matter of their children's religious upbringing.

Moreover, a number of seemingly neutral judicial solutions to religious issues in custody disputes in practice restrict one parent's ability to expose his or her children to religion. In some cases, the custody schedule designed by the court, though designed to respect both parents' religious beliefs, will entirely preclude one parent from engaging in certain religious activities with his or her children ${ }^{183} \mathrm{~A}$ custody determination designed to avoid religious issues entirely may have the same effect. ${ }^{184}$ If the parents do not have an agreement, the Constitution requires the court to leave such restrictions where they fall..$^{125}$ To do otherwise would require a court to give preference to a particular religion or course of religious training. But in those situations, such as Paul and Julie's, where the parents do have an agreement, the most neutral course for the court is to create a custody and visitation schedule based on the child's best interests and then order both parents to comply with the course of religious upbringing outlined in the agreement that they designed themselves. In that way, any restrictions imposed by the parties will be self-imposed, rather than imposed by the court.

If two individuals, such as Paul and Julie, have signed an agreement regarding their children's religious upbringing, each should be deemed to have waived his or her right to direct the children's religious upbringing in a manner not specified in the agreement. A court

183. See supra notes $45-50$ and accompanying text.

184. See, e.g., Rinehimer v. Rinehimer, 485 A.2d 1166, 1168-69 (Pa. Super. Ct. 1984) (stating that court "placed no prohibition upon either parent against taking the children to services of his or her faith, discussing religious beliefs, or in any other way exposing the boys to their respective faiths," but noting that the father was "effectively prevented from taking his sons to Sunday morning services most of the year").

185. See, e.g., Fisher v. Fisher, 324 N.W.2d 582, 585 (M ich. Ct. A pp. 1982) (stating that "in considering which of two parents shall be awarded custody of their children, the court must maintain its constitutionally mandated neutrality with respect to the merits of the religious beliefs of the parties"). 
examining an agreement such as Paul and Julie's should find that waiver valid, and should enforce the agreement. In situations where the parties do not have an agreement, a court has no basis to restrict either party from engaging in religious activities with his or her children, unless those activities pose a risk of substantial harm. B ut if an agreement exists, does not pose such a risk, and does not seem adverse to the children's best interests, a court should enforce it.

The Zummo court wrongly dismissed the possibility that a person's right to free exercise can be waived ${ }^{186}$ Individuals may waive a number of constitutionally protected rights, among them a criminal suspect's right to counsel, ${ }^{187}$ the right to be present at trial ${ }^{188}$ and the privilege against self-incrimination. ${ }^{189}$ In the context of a "contract waiver, before ... any dispute has arisen and whereby a party gives up in advance his constitutional right" to notice and a hearing prior to civil judgement, the Supreme Court has held that waiver is valid when it is "voluntarily, knowing and intelligently made ... or an intentional relinquishment or abandonment of a known right or privilege." ${ }^{190}$

Despite the public policy concerns articulated by the Zummo opinion with respect to waiver of the right to freely exercise one's religion, there is substantial support for the theory that private individuals can waive constitutional rights by contract. ${ }^{191}$ No Supreme Court case has addressed the precise issue facing Paul and Julie. However, analogous precedent suggests that when parties make a

186. See Zummo v. Zummo, 574 A .2d 1130, 1148 (Pa. Super. Ct. 1990) (concluding that religious freedom "may not be bargained away").

187. See Brewer v. Williams, 430 U.S. 387, $403-06$ (1977) (holding that while an accused may waive his right to have counsel present at an interrogation, there was no "intentional relinquishment" of that right in the present case).

188. See Illinois v. A llen, 397 U .S. 337, 343 (1970) (holding that a defendant can lose his right to be present at trial, if, after being warned that he will be removed for disorderly and disruptive conduct, he continues to act in such a manner).

189. See M iranda v. A rizona, 384 U S. 436, 478-79 (1966) (outlining valid waiver of right to counsel and against self-incrimination).

190. D.H. Overmyer Co. v. Frick Co., 405 U.S. 174, 184-86 (1971) (internal quotation marks omitted) (holding that a corporation could validly waive its due process right to notice and a hearing when a property right is involved, finding such a case to be analogous to waiver in a criminal context when personal liberty is involved).

191. Courts may apply the doctrine of unconstitutional conditions to invalidate those contracts between an individual and the government in which the government offers a benefit to the individual on the condition that the recipient perform or forgo an activity that the Constitution usually protects from government interference. E ven in this area, however, the doctrine is applied inconsistently. For a general discussion of this doctrine and its application, see $\mathrm{K}$ athleen M. Sullivan, Unconstitutional Conditions, 102 H A R V. L. R E V. 1413, 1415-17 (1989). 
contract which burdens First A mendment rights, a court can enforce that contract, based on generally applicable rules of contract law, because the parties have imposed the burdens on themselves- that is to say, they have waived their free speech rights. ${ }^{192}$ In Cohen v. Cowles M edia Co., the Supreme Court found that a newspaper may waive its First A mendment free press rights, if a reporter agrees to keep confidential the identity of a news source. ${ }^{193}$ The Court found that enforcement of that agreement did not raise substantial First A mendment issues, despite the fact that the agreement restrained the press from revealing the news source's identity. ${ }^{194}$ The Court found it significant that the restrictions were generated by agreement, as opposed to a state law imposing liability based upon the content of a publication. ${ }^{195}$ By concluding that the burdens were self-imposed, and thereby finding that the First A mendment was not implicated and by refraining from the balancing of government interests and private rights usually required to justify infringement upon Constitutional rights, the Court endorsed the waiver theory. ${ }^{196}$

A s one commentator has noted, the Supreme Court is increasingly unwilling to use the Constitution as a source of public policy to limit rights acquired by contract. ${ }^{197}$ A s a result, a number of state and federal courts have "adopted highly flexible views of contractual waivers of constitutional rights" - including parental rights, First A mendment rights, Fifth A mendment rights, due process and the right to jury trial. ${ }^{198}$ That flexibility should extend to contracts involving rights of free exercise and parental authority.

Paul and J ulie's agreement presents a compelling case for finding that the parties have validly waived one discrete element of their right to contribute to their children's religious upbringing. First, the right waived is particularly narrow. It does not bar either party from discussing religion with his or her children or from engaging in relig-

192. See Cohen v. Cowles M edia Co., 501 U.S. 663, 672 (1991); see also Snepp v. U nited States, 444 U .S. 507, 508 (1980) (per curiam) (upholding the validity of an employment contract in which $\mathrm{ClA}$ employee waived his free speech rights insofar as he agreed not to publish any information related to the agency without prepublication clearance and awarding damages for contractual violation).

193. See Cohen, 501 U .S. at 672.

194. See id. at 669-70.

195. See id. at 670-71.

196. See id. at 677 (Souter, J., dissenting).

197. See G. Richard Shell, Contracts in the Modern Supreme Court, 81 CA L. L. REV. 433, 480 (1993). For an overview of the Court's approach from this perspective, see id. at 477-80.

198. See id. at 486 (collecting cases). 
ious rituals or activities with his or her children in the home. Nor does it restrict either person's right to attend church, or religious activities, if those activities do not involve his or her children. If parties may freely waive rights involving other liberties protected by the Bill of Rights, ${ }_{199}^{199}$ a court should not refuse to recognize a waiver of the right to direct the religious upbringing of one's children. Second, the contract provides clear and unambiguous evidence that both parties knowingly and voluntarily relinquished their constitutional rights. ${ }^{200}$

\section{CONCLUSION}

A ntenuptial religious upbringing agreements allow parties, especially those in interfaith marriages, to reduce the risk of conflict regarding their children's religious upbringing during the marriage. In crafting such agreements, parties are forced to confront their religious attitudes, as well as their need to share those attitudes with their children. As the Z ummo court recognized, these agreements may "serve an important and beneficial purpose by promoting careful consideration of potential difficulties prior to marriage." 201 If the parents do divorce, an enforceable agreement ensures that their children's program of religious training will continue as agreed upon. The agreement does not reduce all risk-for either parent is free, during or after the marriage, to attempt to influence or indoctrinate the children in a number of ways, excluding only formal training, services and activities. ${ }^{202} \mathrm{~A}$ couple who chooses to intermarry will be unable to exclude the possibility that their children will share, to some extent, in the religious traditions of both parents. ${ }^{203}$ They are

199. See $M$ arshall, supra note 45 , at 233-34 (affirming individual's ability to waive his free exercise rights but questioning whether, in the context of a prenuptial agreement, the parties can be shown to have done so knowingly and voluntarily).

200. See supra note 190 and accompanying text.

201. Zummo v. Zummo, 574 A .2d 1130, 1147 n.30 (Pa. Super. Ct. 1990).

202. This type of influence is not insignificant, and, in extreme circumstances, may even be damaging to a child. See, e.g., Schwarzman v. Schwarzman, 388 N.Y.S.2d 993, 999 (N.Y. Sup. Ct. 1976) (observing that "the father utilizes his visitation time to proselytize with the children, admonishing them that they are J ews, that their mother is doing a sinful thing by taking them to her Church and that they will suffer the fires of hell if they accede to their mother's religious indoctrination").

203. The court in Zummo noted that:

Couples typically anticipate at the beginning of their relationship that they can overcome all odds in marriage.... one spouse may fuse into the other's family by religious conversions, ... . or by adopting the accoutrements of the other's culture. 
thus forced to internalize some of the risks ${ }^{204}$ of intermarriage, but allowed the measure of protection afforded to all individuals and institutions who make contracts to secure and protect their rights.

[H owever, a] spouse who marries out ... and raises children without teaching them his or her native language or cultural traditions may later regret that decision, as the children grow up with little sense of [his or her suppressed] ethnic identity.

574 A .2d at 1147 n.30 (second alteration in original) (quoting Monica M cG oldrick \& Nydia Preto, E thnic Intermarriage, 23 FA M. PR OCE SS 347, 347-48, 352, 357 (1984)).

204. Were the religious upbringing agreement unenforceable, each party would be forced to assume the risk that the other might refuse to abide by agreement. Perhaps then, those who conditioned their interfaith marriages on religious upbringing agreements would be less likely to enter into interfaith marriages, and would seek partners with similar religious backgrounds, which would reduce the risk of marital conflict regarding religious matters. Whether or not this is a desirable result, it does not justify the denial of the protection of civil courts to those who rely on these agreements when entering into interfaith marriages. 


\title{
A PPENDIX
}

\author{
MODEL ANTENUPTUAL A GREEMENT \\ REGARDING RELIGIOUSUPBRINGING OF CHILDREN \\ PRODUCED BY THE MARRIAGE
}

We, and of state, make this agreement in order to resolve the issue of the religious upbringing of any children we will have during the course of our marriage. We are advised by separate counsel, and agree willingly and voluntarily to the provisions herein, having taken due time to consider their contents. We intend this contract to apply throughout the course of our marriage, and were we to divorce, upon divorce. of [religious faith] and of the J ewish faith, hereby agree that our children will be raised in the Jewish faith. Our children will be members of Synagogue, which practices R eform Judaism. We agree that our children, if male will be circumcised at age [ ], and if female, will be named in a naming ceremony, both to take place at Synagogue and be conducted by a Rabbi. We agree that our children will attend secular schools for their general education, but will attend the religious school at Synagogue, every Sunday, from age 5 onward. We agree that our children will attend Friday and Saturday night services at Synagogue, and will attend services on R osh $\mathrm{H}$ ashanah and $\overline{\mathrm{Y}}$ om $\mathrm{K}$ ippur from age 1 onward. A t age 8, our children will attend the summer camp run by Synagogue, for the first six weeks of each summer. A t age $\overline{12}$, our children will begin preparing to be bar/bat mitzvah at Synagogue.

Our children will not attend the religious services, schools or camps run by any other religious organization. O ur children will participate in religious services of [religious faith of other parent] when those services are part of a baptism, christening, confirmation, wedding or funeral of a member of the family of of [religious faith]. 